\title{
Petrogenesis of mica-amphibole-bearing lamprophyres associated with the Paleoproterozoic Morro do Afonso syenite intrusion, eastern Brazil
}

\author{
J. Plá Cid *, D.C. Rios, H. Conceição \\ CPGG, Instituto de Geociências, Universidade Federal da Bahia, Rua Caetano Moura 123, Salvador, Bahia CEP 40210-350, Brazil
}

Received 1 August 2004; accepted 1 March 2006

\begin{abstract}
Mica-amphibole-lamprophyres, identified as vogesites, are associated with the Paleoproterozoic Morro do Afonso syenite intrusion in northeastern Brazil. The lamprophyres occur mainly as dykes that crosscut the syenitic rocks and occasionally as enclaves. Lamprophyric rocks are formed by the early magmatic paragenesis amphibole-clinopyroxene-apatite-phlogopite-ilmenite; feldspars are found in the groundmass. Near liquidus amphibole is edenite, close to the boundary with pargasite, which is enriched in alkalis relative to the other amphiboles (Mg-hornblende and actinolite). Clinopyroxene is diopside, and inclusions of phlogopite are analyzed in both clinopyroxene and amphibole phenocrysts. The chemical evolution of the mafic minerals is consistent with increasing oxygen fugacity during late magmatic stages. Whole-rock geochemical data suggest a metaluminous, ultrapotassic parental liquid, with silica saturation close to the limit of undersaturation. Trace element concentrations, such as enrichment in large ion lithophile and strong depletion of some high fieldstrength elements, indicate a mantle source that was partially modified by a subduction event. In this metasomatic mantle, it is important to emphasize the strong enrichment of light rare-earth elements, which is higher than those typically associated with basaltic rocks from active continental margins, and corresponding concentrations similar to those determined in lamproitic rocks. Major element modeling shows that fractional crystallization and magma flow segregation are the main petrogenetic processes involved in the magmatic evolution of lamprophyre magma, and it is possible to generate syenite magma by these mechanisms.
\end{abstract}

(c) 2006 Elsevier Ltd. All rights reserved.

Keywords: Mica-amphibole-lamprophyres; Vogesites; Mineralogy; Ultrapotassic rocks; Petrology, Brazil

\section{Introduction}

Lamprophyres are generically referred to as ultramafic, mafic, or intermediate rocks that intrude the basement at shallow-crustal levels and form dykes and/or sills. Furthermore, lamprophyres are porphyritic rocks comprising phenocrysts of mafic minerals and apatite, set in a groundmass that usually consists of the same early crystallized minerals, plus alkali feldspar and/or plagioclase. Among the early magmatic mafic minerals are phlogopite, olivine, amphibole, clinopyroxene, and apatite. The mineralogy of lam-

\footnotetext{
* Corresponding author.

E-mail address: jorge.pla@bol.com.br (J. Plá Cid).
}

prophyres is diverse, including ilmenite, garnet, titanite, allanite, sulfide, quartz, carbonate, zircon, thorite, monazite, and other minor phases as well. Extensive reviews of lamprophyric rocks can be found in Bergman (1987) and Rock (1987, 1991). Although lamprophyres have been considered late intrusions, Barnes et al. (1986) and Ayrton (1991) show that such magmas intrude granite systems during crystallization and Sabatier (1991) describes lamprophyric mafic microgranular enclaves in magnesiumpotassic Hercynian granites. Plá Cid et al. (2002, 2003) present enclaves of minette composition mingled at upper mantle pressures with potassic syenitic magmas from southern Brazil.

Petrographic relationships observed in both lamprophyres and lamproites suggest that such rocks crystallize from 
volatile-rich magma produced from a metasomatized mantle source. The petrogenetic model of metasomatic mantle was developed initially to explain a worldwide range of intraplate oceanic and continental magmas, usually with alkaline signature, that presented geochemical and isotopic features typical of subduction-related settings. Among these alkaline magmas are lamproites and lamprophyres (Ringwood, 1990). The first studies to attempt to identify and classify the components and reservoirs of the mantle sources were developed by McCulloch et al. (1983), White (1985), and Zindler and Hart (1986). However, Hofmann and White (1980) and Ringwood (1982) suggest that subduction of basaltic oceanic crust is connected with the petrogenetic processes responsible for the source composition of intraplate magmas. Kesson and Ringwood (1989) explore the theory that partial melting of the oceanic crust occurred between 100 and $300 \mathrm{~km}$, and the partial melts migrated to the lithosphere mantle wedge, composed of depleted peridotite, and promoted a refertilization of the region. Furthermore, many studies (e.g., Esperança and Holloway, 1987; McKenzie, 1989; Ringwood, 1990; Foley, 1992; Gibson et al., 1993; Mitchell, 1995; Chazot et al., 1996) of mantle metasomatism, mechanisms of fertilization, petrogenetic processes, source mineralogy, and products have been developed, though it is not the aim of this article to discuss them.

Lamprophyres are frequently related to orogenic settings, because oceanic plate subduction may promote metasomatism in the lithosphere mantle. Even in areas lacking evidence of an actual subduction setting, geologic events suggest that a paleosubducted slab may have modified the mantle. In this way, the record of an ancient metasomatic event may be preserved during several hundred million years by the lithosphere mantle (Wilson, 1989; Gibson et al., 1995).

In Bahia (Fig. 1), eastern Brazil, four occurrences of calc-alkaline to alkaline lamprophyric rocks have been described, in association with syenites and volcanosedimentary sequences: (1) in Potiraguá, south Bahia, spessartites are described in association with undersaturated Neoproterozoic syenites (Souto, 1972); (2) in the monzosyenite Guanambi-Urandi Batholith, southwestern Bahia, minettes are described in association with the 2.1 Ga Cara Suja alkali feldspar syenite (Paim et al., 2002); (3) in the carbonatite complex of Angico dos Dias, north Bahia, alkali-lamprophyres are associated with silica-saturated syenites and carbonatites of Paleoproterozoic age (Silva et al., 1988); and (4) in the Morro do Afonso Syenite Pluton (MASP), northeastern Bahia, vogesites, initially identified by Conceição et al. (1995), are associated with alkalifeldspar syenites and gold mineralization (Vasconcelos and Becker, 1992).

The MASP has an estimated crystallization age between $2081 \pm 27$ and $2098 \pm 9 \mathrm{Ma}$, according to $\mathrm{Pb}-\mathrm{Pb}$ isotopic data using the zircon evaporation method (Rios, 2002). However, $T_{\mathrm{DM}}$ ages obtained through the $\mathrm{Sm}-\mathrm{Nd}$ isotopic method suggest an Archean/Paleoproterozoic minimum extraction age of 2.56-2.58 Ga for the parental magma of this syenite intrusion (Rios, 2002). Similar results were found by Rios (2002) in other K-enriched intrusions of the Serrinha nucleus, as well as by Rosa (1999) in potassic and ultrapotassic syenites and monzonites from western Bahia. We believe the similar Archean $T_{\mathrm{DM}}$ values determined for all K-enriched plutons, widespread in São Francisco Craton, preclude the significant role of continental crust contamination during the rise of alkaline magmas. Therefore, such values are probably related to the extraction age of primary magmas from a mantle source, probably metasomatized during the Archean by subducted slab dehydration.

This article deals with the petrographic, mineralogical, and geochemical aspects of lamprophyres associated with the MASP, as well as their petrogenetic relationship with the host syenite rocks.

\section{Geological setting}

In Bahia state, there are three Archaean nuclei-Serrinha (SerN), Remanso, and Guanambi-separated by Paleoproterozoic orogenic belts (Fig. 1) that form the São Francisco Craton (Mascarenhas, 1979). At SerN, interpreted as a granite-greenstone association, and along the orogenic belts, several Paleoproterozoic syenite intrusions occur (Conceição, 1993; Rios, 1997; Rosa, 1999; Conceição et al., 2000, 2002). The late- and posttectonic rocks of SerN, similar to the greenstone belt of Abitibi, Canada (Wyman and Kerrich, 1988), are represented by granodiorites, monzonites, syenites, syenodiorites, and shoshonites (Matos and Conceição, 1993; Rios, 1997, 2002; Conceição et al., 2002). The syenites occur as discrete intrusions, cross-cutting the greenstone belts and/or Archaean gneisses, and thus postdate the major crustforming events. One syenitic intrusion is represented by the MASP. In this pluton, lamprophyres are contemporaneous with the syenite magmatism, as indicated by observed liquid relationships (Rios, 1997). In the Cara Suja Massif, the typical lamprophyre-syenite-greenstone belt association occurs, and gold mineralization has been detected in the lamprophyric and syenitic rocks. In this region, massif sulfide bodies are closely related to the syenite intrusion.

The lamprophyres associated with the MASP occur as enclaves and dykes. Dykes are generally less than $0.5 \mathrm{~m}$ wide but can reach up to $80 \mathrm{~m}$. The contacts with the feldspar-rich cumulate syenites are sharp and irregular and occasionally globular with other syenite facies. Locally, the lamprophyre magma shows assimilation of feldspar xenocrysts. The enclaves are normally round or oval in shape, with an average diameter of $15 \mathrm{~cm}$. Chilled margins, observed only in wider dykes, are less than $5 \mathrm{~cm}$ wide and occur close to the sharp contacts between lamprophyre and feldspar-rich cumulate syenites, where feldspar crystals from syenitic rocks are partially corroded and recrystallized. 


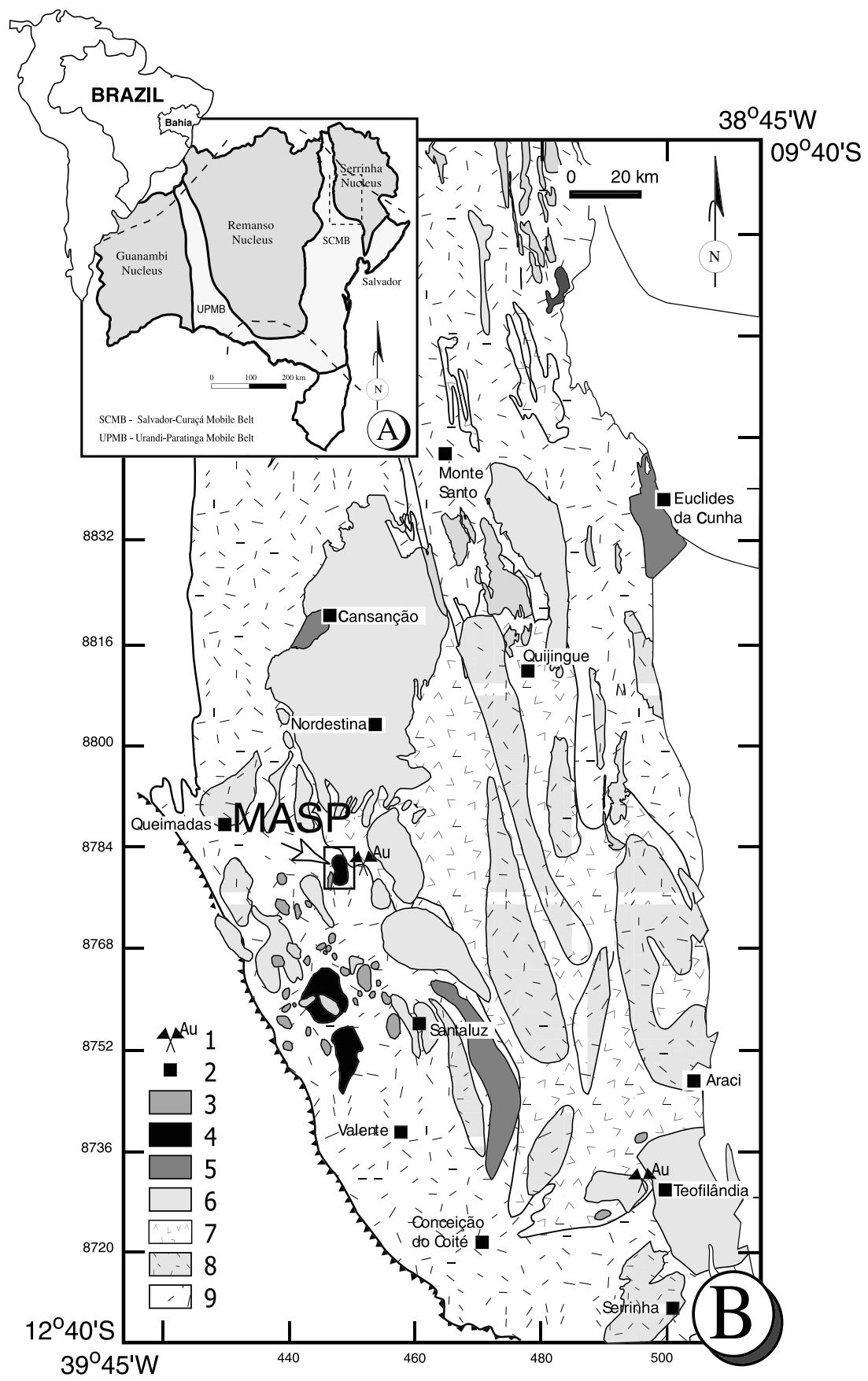

Fig. 1. (A) Archaean nuclei in Bahia (Mascarenhas, 1979) and Paleoproterozoic Mobile belts (Conceição, 1990). (B) Geological sketch of the Serrinha block, showing (shaded areas) Archaean and Paleoproterozoic granite and syenite magmatism (Rios, 1997). (1) Maria Preta gold mine; (2) villages; (3) Paleoproterozoic Morro do Lopes-type shoshonitic rocks; (4) Paleoproterozoic potassic rocks, including MASP; (5) Paleoproterozoic Itareru-type shoshonitic rocks; (6) Paleoproterozoic calc-alkaline rocks; (7) Paleoproterozoic Rio Itapicuru greenstone belt; (8) Archaean calc-alkaline granites; (9) Archaean basement.

The lamprophyre dykes occur in two different ways: (1) discontinuous synplutonic dikes with irregular shapes, locally showing internal pillow structures, suggesting the coexistence of lamprophyre and intermediate mafic-syenite magmas or (2) tabular dikes, cutting the magmatic flow structure of the host syenite. Internal accumulation of mafic minerals is observed in some dikes, due to the segregation promoted by magmatic flow. The mode of the lamprophyres suggests that magma intruded the syenitic host at different stages during MASP crystallization (Rios, 1997, 2002).

Syenite rocks from the Morro do Afonso intrusion cover a semicircular area of approximately $12 \mathrm{~km}^{2}$. Three different facies are identified by Rios (1997): leucocratic, mesocratic, and leucocratic syenites with features of alkali feldspar accumulation. 


\section{Petrographic features}

The lamprophyres of MASP are meso- to melanocratic rocks, slightly anisotropic, and display porphyritic and glomero-porphyritic, allotriomorphic to panidiomorphic textures.

The early minerals comprise clinopyroxene, mica, amphibole, and apatite. The alkali feldspar-rich groundmass exhibits phaneritic, fine-grained textures and well-preserved magmatic flow structures, which contain large amounts of amphibole, clinopyroxene, and mica, as well as rare albite-oligoclase. According to Le Maitre et al. (1989), these rocks are vogesites (amphiboles $>$ mica). Zircon, titanite, apatite, Fe-Ti oxides, sulfide, carbonates, quartz, epidote, monazite, and allanite can occur as accessory phases. The lamprophyres have abundant phenocrysts of amphibole and mica, which range in size from 1 to $4 \mathrm{~cm}$, and are commonly zoned and twinned. Some clinopyroxene phenocrysts have amphibole rims produced by latemagmatic reequilibrium. Electron microprobe images reveal the presence of amphibole microinclusions in some clinopyroxene crystals, which suggests amphibole was an early magmatic phase. Apatite occurs as euhedral crystals included in clinopyroxene and mica phenocrysts. Centimeter-sized (up to $10.0 \mathrm{~cm}$ ) gray crystals of strongly zoned alkali feldspar also are observed. These feldspars show adsorption and corrosion textures and are interpreted as xenocrysts from the syenite host rocks (Conceição et al., 1995). The orientation of phenocrysts and groundmass minerals in the lamprophyre dikes suggests a nearly Newtonian flow.

The crystallization order in the lamprophyres (Rios, 1997) shows the early magmatic paragenesis is apatiteclinopyroxene-mica with lesser amounts of amphibole, $\mathrm{Fe}-\mathrm{Ti}$ oxides, monazite, and zircon. In the late magmatic stages, these same minerals crystallize in low proportions, along with alkali feldspar, oligoclase, occasionally quartz, Fe-oxide, titanite, carbonate, and other accessory phases.

\section{Mineral chemistry}

Mineral chemistry studies were carried out only for the mafic phases (e.g., mica, clinopyroxene, and amphibole), because these minerals better reflect conditions of the early magma composition.

The chemical composition of minerals of the Morro do Afonso lamprophyres was obtained with an electron microprobe CAMECA SX-50 at the Electron Probe Laboratories of the Universidade Federal do Rio Grande do Sul, Brazil, and the Serveis Cientificotècnics of Universitat de Barcelona, Spain. Analytical conditions included a beam current of $10 \mathrm{nA}$, beam energy of $15 \mathrm{keV}$, and a spot size of $1 \mu \mathrm{m}$. Acquisition time was $20 \mathrm{~s}$ on the peak and $10 \mathrm{~s}$ on the background. Each element was standardized on either synthetic or natural minerals. Ferric iron was calculated by stoichiometry by the microprobe software and checked against the suggestions of Dropp (1987), as well as through Minpet 2.01 software.

\subsection{Mica}

Representative analyses of mica crystals from Morro do Afonso lamprophyres are presented in Table 1. The analyzed crystals are represented by phenocrysts, groundmass, and microinclusions in clinopyroxene and amphibole. Mica compositions belong to the biotite field, except for two analyses of cores of inclusions, which are phlogopitic $\left(\mathrm{Mg} / \mathrm{Mg}+\mathrm{Fe}^{2+}>0.66\right)$ in composition (Fig. 2). The phlogopite crystals have $\mathrm{Mg} / \mathrm{Mg}+\mathrm{Fe}^{2+}$ ratios up to 0.68 , whereas in the biotite grains, the values range between 0.51 and 0.61 . Fig. 2 shows the progressive decrease in the $\mathrm{Mg} / \mathrm{Mg}+\mathrm{Fe}^{2+}$ ratio from included grains to phenocrysts and groundmass crystals. These high $\mathrm{Mg}$ concentrations relative to $\mathrm{Fe}^{2+}$ indicate early magmatic crystallization. Such geochemical behavior has been observed in micas of the lamprophyres from Cara Suja intrusion, southwest Bahia (Fig. 2), which presents textural relations similar to those of MASP.

Micas from lamprophyres associated with syenites from three different localities in Brazil plot close to or along the boundary between alkaline and calc-alkaline series (Fig. 3). The relatively homogeneous composition of these micas reflects the original composition of the magma; large-scale contamination by syenite magma is unlikely. The discriminating diagram of Abdel-Rahman (1993) is not usually applied to micas crystallized from potassic and ultrapotassic magmas, but it seems most of the grains plot in a restricted region of this plot. This finding may indicate that the alkaline/calc-alkaline boundary is the compositional region in which mica grains crystallized from such magmas plot.

The composition of groundmass crystals and phenocrysts is nearly the same, reflecting crystallization in similar conditions. Relative to $\mathrm{Si}$, we identify two groups. The first group is formed of inclusions, mostly groundmass crystals, and phenocrysts, in which Si progressively decreases from 6.19 to $5.85 \mathrm{apfu}$, whereas $\mathrm{Al}_{\text {total }}$ contents remain constant around $2.5 \mathrm{apfu}$. Phlogopite inclusions have the highest $\mathrm{Si}$ amounts, and the Si decrease is not followed by an increase in $\mathrm{Al}$ concentrations (Table 1). Therefore, ${ }^{\mathrm{VI}} \mathrm{Al}$ also decreases, as observed by its variation from 0.72 to 0.14 apfu (Table 1). Tetrahedral aluminum may be progressively incorporated in the substitution of $\mathrm{Si}$, whereas $\mathrm{Al}_{\text {total }}$ remains the same. The second group consists of some groundmass grains and one phenocryst belonging to the same sample (1281), which is richer in ${ }^{\mathrm{VI}} \mathrm{Al}$ than the first group, for similar Si contents. The higher concentration of $\mathrm{Al}_{2} \mathrm{O}_{3}$ in this sample explains this compositional characteristic. Substitutional schemes for mica suggest that decreasing $\mathrm{Mg}$ together with ${ }^{\mathrm{VI}} \mathrm{Al}$ is followed by the progressive incorporation of $\mathrm{Fe}^{2+}$ plus $\mathrm{Ti}$, according to the substitution $\mathrm{Mg}^{2+}+{ }^{\mathrm{VI}} \mathrm{Al}^{3+} \rightarrow \mathrm{Fe}^{2+}+\mathrm{Ti}^{4+}$ (Fig. 4), balanced by substitution of Si by ${ }^{\mathrm{IV}} \mathrm{Al}$. The increase of iron 
Table 1

Representative analyses of micas from Morro do Afonso lamprophyres

\begin{tabular}{|c|c|c|c|c|c|c|c|c|c|c|c|c|c|c|c|c|}
\hline Type & Inc. & Inc. & Inc. & Inc. & Inc. & Grd. & Grd. & Grd. & Grd. & Grd. & Pheno. & Pheno. & Pheno. & Pheno. & Pheno. & L.-Mt. \\
\hline $\mathrm{SiO}_{2}$ & 38.81 & 39.77 & 36.53 & 35.79 & 36.54 & 37.21 & 36.53 & 36.84 & 37.51 & 37.41 & 36.58 & 37.42 & 37.72 & 38.42 & 38.01 & 36.75 \\
\hline $\mathrm{TiO}_{2}$ & 0.71 & 1.03 & 1.31 & 1.25 & 4.45 & 1.28 & 1.86 & 2.14 & 2.95 & 3.05 & 1.84 & 1.86 & 1.50 & 0.89 & 1.46 & 1.24 \\
\hline $\mathrm{Al}_{2} \mathrm{O}_{3}$ & 13.82 & 13.55 & 12.79 & 12.85 & 12.15 & 14.64 & 14.43 & 14.60 & 14.44 & 14.23 & 14.45 & 14.50 & 13.60 & 13.80 & 13.90 & 13.27 \\
\hline $\mathrm{AnO}$ & 0.10 & 0.29 & 0.24 & 0.36 & 0.29 & 0.23 & 0.19 & 0.20 & 0.17 & 0.16 & 0.19 & 0.17 & 0.26 & 0.25 & 0.27 & 0.24 \\
\hline $\mathrm{MgO}$ & 16.29 & 16.37 & 15.01 & 14.71 & 14.14 & 11.95 & 11.64 & 11.77 & 13.31 & 13.46 & 11.84 & 11.75 & 12.98 & 13.68 & 13.10 & 13.40 \\
\hline $\mathrm{BaO}$ & 0.00 & 0.00 & 0.54 & 0.23 & 0.48 & 0.11 & 0.00 & 0.11 & 0.11 & 0.00 & 0.40 & 0.06 & 0.25 & 0.00 & 0.21 & 0.13 \\
\hline $\mathrm{K}_{2} \mathrm{O}$ & 10.06 & 9.81 & 9.79 & 9.55 & 8.86 & 9.77 & 9.89 & 9.94 & 9.72 & 9.70 & 9.75 & 10.13 & 9.78 & 9.76 & 9. & 9.78 \\
\hline & 1.25 & 1.35 & 1.15 & 0.69 & 0.77 & 0.77 & 0.68 & 0.52 & 0.71 & 0.75 & 0.51 & 0.48 & 0.86 & 0.8 & 1. & 0.98 \\
\hline $\mathrm{H}_{2} \mathrm{O}$ & 1.29 & 1.27 & 1.29 & 1.48 & 1.51 & 1.49 & 1.52 & 1.61 & 1.56 & 1.53 & 1.62 & 1.65 & 1.46 & 1.49 & 1.33 & 1.38 \\
\hline ubtotal & 96.23 & 97.56 & 95.77 & 93.89 & 97.11 & 96.94 & 96.09 & 96.95 & 97.39 & 96.68 & 97.30 & 98.11 & 97.08 & 96.72 & 97.36 & 96.01 \\
\hline O_F & 54 & 0.58 & 0.48 & .29 & 0.32 & 0.33 & 0.29 & 0.22 & 0.30 & 0.32 & 0.21 & 0.20 & 0.36 & 0.34 & 0.49 & 0.41 \\
\hline Total & 95.69 & 96.98 & 95.29 & 93.60 & 96.79 & 96.61 & 95.80 & 96.73 & 97.09 & 96.36 & 97.09 & 97.91 & 96.72 & 96.38 & 96.87 & 95.60 \\
\hline $\mathrm{Ti}$ & 0.09 & 0.12 & 0.16 & 0.16 & 0.54 & 0.16 & 0.23 & 0.26 & 0.35 & 0.36 & & & 0.18 & & 0.18 & 0.15 \\
\hline $\mathrm{Fe}^{2+}$ & 1.81 & 1.82 & 2.34 & 2.35 & 2.20 & 2.61 & 2.63 & 2.58 & 2.22 & 2.16 & 2.72 & 2.67 & 2.51 & 2.34 & 2.43 & 2.57 \\
\hline $\mathrm{Mn}$ & 0.01 & 0.04 & 0.03 & 0.05 & 0.04 & 0.03 & 0.03 & 0.03 & 0.02 & 0.02 & 0.03 & 0.02 & 0.04 & 0.03 & 0.04 & 0.03 \\
\hline $\mathrm{Mg}$ & 3.84 & 3.80 & 3.65 & 3.63 & 3.37 & 2.87 & 2.82 & 2.82 & 3.14 & 3.19 & 2.85 & 2.79 & 3.11 & 3.25 & 3.12 & 3.26 \\
\hline $\mathrm{Ba}$ & 0.00 & 0.00 & 0.03 & 0.02 & 0.03 & 0.01 & 0.00 & 0.01 & 0.01 & 0.00 & 0.03 & 0.00 & 0.02 & 0.00 & 0.01 & 0.01 \\
\hline $\mathrm{Ca}$ & 0.01 & 0.01 & 0.00 & 0.00 & 0.23 & 0.01 & 0.00 & 0.01 & 0.01 & 0.02 & 0.00 & 0.00 & 0.00 & 0.01 & 0.00 & 0.00 \\
\hline $\mathrm{Na}$ & 0.00 & 0.00 & 0.00 & 0.00 & 0.04 & 0.00 & 0.00 & 0.00 & 0.00 & 0.00 & 0.00 & 0.00 & 0.00 & 0.00 & 0.00 & 0.00 \\
\hline K & 2.03 & 1.95 & 2.04 & 2.02 & 1.81 & 2.01 & 2.05 & 2.04 & 1.96 & 1.97 & 2.01 & 2.06 & 2.00 & 1.99 & 1.96 & 2.04 \\
\hline Cations & 16.50 & 16.41 & 16.67 & 16.67 & 16.39 & 16.46 & 16.47 & 16.44 & 16.35 & 16.34 & 16.50 & 16.47 & 16.48 & 16.46 & 16.43 & 16.60 \\
\hline $\mathrm{Mg} /(\mathrm{Mg}+\mathrm{Fe})$ & 0.68 & 0.68 & 0.61 & 0.61 & 0.60 & 0.52 & 0.52 & 0.52 & 0.59 & 0.60 & 0.51 & 0.51 & 0.55 & 0.58 & 0.56 & 0.56 \\
\hline
\end{tabular}

Abbreviations: Inc., included grains; Grd., groundmass grains; Pheno, phenocrysts; L.-Mt, late magmatic grains.

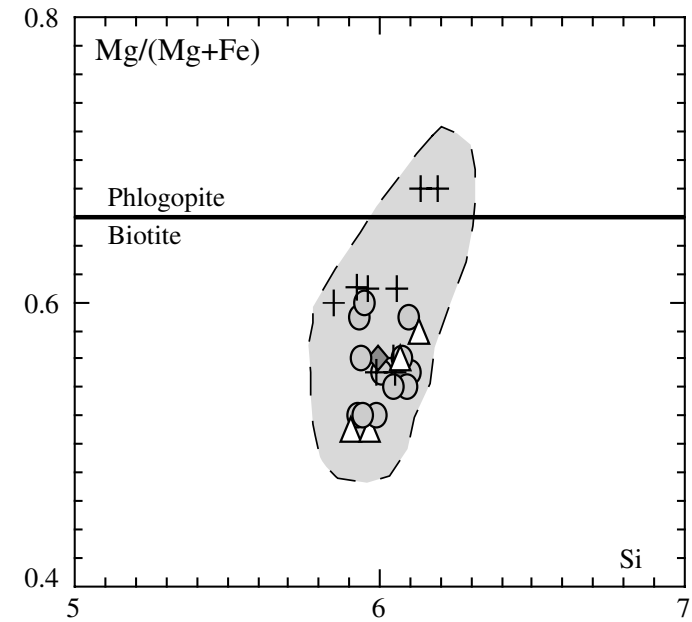

Fig. 2. Classification diagram for micas (apfu), after Rieder et al. (1998). Crosses, inclusions (core); circles, groundmass crystals; triangles, phenocrysts. Shaded area, Cara Suja lamprophyres.

and titanium to the mica borders is corroborated by the appearance of $\mathrm{Fe}$-oxide surrounded by titanite rims at later magmatic stages, as observed in other similar lamprophyric suites (Paim et al., 2002). Such behavior is corroborated by various data (e.g., Métais et al., 1962; Carmichael, 1967;

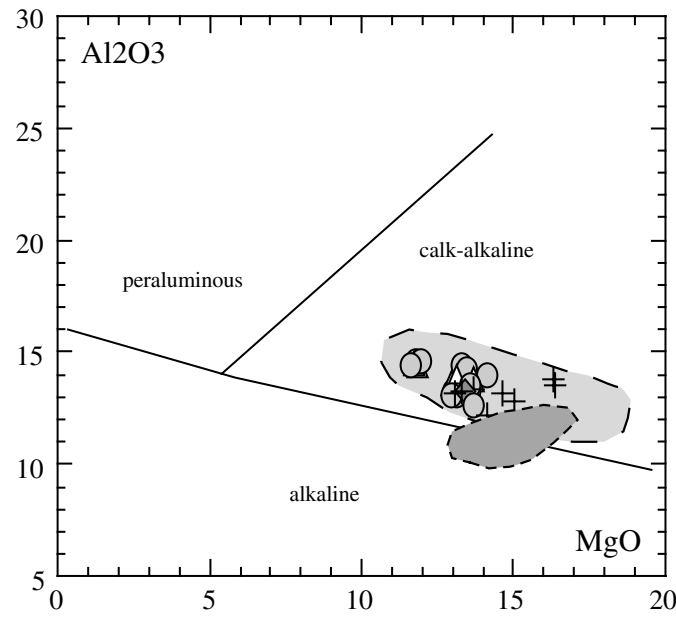

Fig. 3. $\mathrm{Al}_{2} \mathrm{O}_{3}$ versus $\mathrm{MgO}$ (in wt\%) diagram (Abdel-Rahman, 1993) showing the compositional fields of micas from different magmatic series. Crosses, inclusions (core); circles, groundmass crystals; triangles, phenocrysts. Shaded areas: dark, Piquiri lamprophyres, southern Brazil (Plá Cid et al., 2003); light, Cara Suja lamprophyres (Paim et al., 2002).

Velde, 1969; Boetcher et al., 1977; Jones et al., 1982) pertaining to micas from potassic and ultrapotassic rocks. Fluorine seems to be a good indicator of the early character 


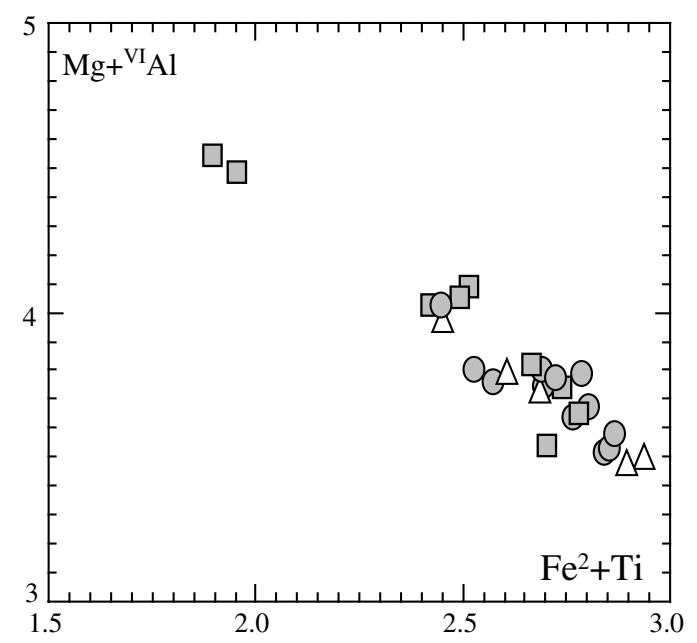

Fig. 4. Substitution scheme of micas from Morro do Afonso (apfu). Squares, inclusions; circles, groundmass crystals; triangles, phenocrysts.

of these mica grains. Phlogopite inclusions have intermediate $\mathrm{F}$-concentrations reaching up to $0.87 \mathrm{wt} \%$, whereas the other grains present less than $0.6 \mathrm{wt} \%$.

The MASP lamprophyre mica has low $\mathrm{TiO}_{2}$ contents, between 1 and $2 \mathrm{wt} \%$ in most grains. Paim et al. (2002) determine similar concentrations in mica from minettes associated with the Cara Suja syenite Massif. However, mica crystals from the two lamprophyre associations present different amounts of fluorine, the Cara Suja Massif may reach $4.1 \mathrm{wt} \%$. Intermediate values of fluorine $(1-2 \mathrm{wt} \%)$ in mica crystals were also measured by Plá Cid et al. (2003) in the Neoproterozoic minettes associated with the Piquiri syenite, southern Brazil. The average fluorine contents of micas from lamprophyres have been determined by different authors, such as Nemec (1968), Kramer (1976), and Luhr and Carmichael (1981), who find values around $1.11 \mathrm{wt} \%$. $\mathrm{BaO}$ is normally below detection limits. When detected, it appears to show compatible behavior, in that the phlogopite inclusions are normally richer than groundmass crystals and phenocrysts (Table 1). However, several analyses of inclusions show $\mathrm{BaO}$ contents below the detection limit, as do some groundmass and phenocrysts analyses.

\subsection{Amphibole}

Representative analyses of amphibole grains are presented in Table 2. The analyses were undertaken on microinclusions and rims in clinopyroxene phenocrysts, amphibole phenocrysts, euhedral groundmass crystals, and transformed zones on clinopyroxene phenocrysts. Amphibole compositions belong to the calcic group, according to the classifications proposed by Leake et al. (1997). Most inclusions are edenite, because the alkali $(\mathrm{Na}+\mathrm{K})$ content is higher than $0.5 \mathrm{apfu}$. The less evolved edenite crystals of MASP lamprophyres plot on the boundary between edenite and pargasite $\left({ }^{\mathrm{VI}} \mathrm{Al}>\mathrm{Fe}^{3+}\right)$ or $\mathrm{Mg}$ - hastingsite $\left({ }^{\mathrm{VI}} \mathrm{Al}<\mathrm{Fe}^{3+}\right)$ compositions (Fig. 5). Groundmass crystals, phenocrysts, and amphibole rims range between Mg-hornblende and actinolite. Edenite inclusions are characterized by higher $\mathrm{Mg} /\left(\mathrm{Mg}+\mathrm{Fe}^{2+}\right)$ ratios compared with Mg-hornblende groundmass and phenocrysts (Fig. 5). The Mg-hornblende and actinolite amphiboles have a lower $\mathrm{Mg} /\left(\mathrm{Mg}+\mathrm{Fe}^{2+}\right)$ ratios but an evolutionary trend parallel to that found in edenite inclusions.

Fig. 5 denotes two evolution lines, both showing an increase of the $\mathrm{Mg} /\left(\mathrm{Mg}+\mathrm{Fe}^{2+}\right)$ ratio together with $\mathrm{Si}$. Such a compositional gap may suggest that amphibole crystallized at two different stages in the lamprophyre magma. Alternatively, it may be explained by variations in the oxygen fugacity of the magma. Amphibole inclusions are associated with $\mathrm{Fe}$-Ti-oxides, which may explain their higher $\mathrm{Mg} /\left(\mathrm{Mg}+\mathrm{Fe}^{2+}\right)$ ratios. A younger generation of oxides is observed only in the late magmatic stages, when amphibole composition is characterized by high $\mathrm{Mg} /$ $\left(\mathrm{Mg}+\mathrm{Fe}^{2+}\right)$ ratios. In addition, edenite grains have preserved their composition since they were included in diopside crystals. Free-amphibole crystals reacted with the magma in new physicochemical conditions, producing the compositional gap. Thus, the difference between inclusions and the other amphiboles shows the geochemical change of the magma.

The amphibole composition of the Cara Suja lamprophyres (Paim et al., 2002) is very similar to that observed in the MASP, though the inclusions of amphibole in diopside phenocrysts were not observed in Cara Suja lamprophyres. In minettes associated with the Piquiri syenite (Plá Cid et al., 2003), amphibole occurs as microinclusions and exsolutions inside diopside phenocrysts. Such amphiboles are edenite, $\mathrm{Mg}$-hornblende, and actinolite, and as in the Morro do Afonso lamprophyre, amphibole is a probable near liquidus phase.

The edenite inclusions have an A-site occupancy reaching up to $0.79 \mathrm{apfu}$, and the alkali content in this site decreases to $0.51 \mathrm{apfu}$ with an increase (6.51-6.97 apfu) in Si contents (Fig. 6). This behavior is similar to that in other types of amphibole, with progressive loss of alkalis and incorporation of Si. The early crystallization of alkali-rich amphiboles indicates the strongly alkaline nature of the primary magma. Such evolution is the opposite of that observed in mica, which evolves with decreasing $\mathrm{Si}$ concentrations. The Si content in amphibole is normally related to the magma Si contents (Giret et al., 1980), which in these lamprophyres is not true for mica. This antipathetic behavior of the hydrated phases is probably related to the $\mathrm{Si}$ increase in the magma during fractionation, as attested by the late crystallization of alkali feldspar. The evolution is also characterized by a decrease in $\mathrm{Ti}$ concentrations in the late magmatic amphiboles, probably reflecting simultaneous crystallization of titanite (Fig. 6).

$\mathrm{Fe}^{2+}, \mathrm{Fe}^{3+}$, and $\mathrm{Mg}$ contents in edenite inclusions differ from the other amphibole crystals of the Morro do Afonso lamprophyres. Concentrations of these elements are relatively homogeneous in the inclusions, suggesting crystalli- 
Table 2

Representative analyses of amphiboles from Morro do Afonso lamprophyres

\begin{tabular}{|c|c|c|c|c|c|c|c|c|c|c|c|c|c|c|c|c|c|c|}
\hline Type & Incl. & Incl. & Incl. & Incl. & Incl. & Grd-c. & Grd-c. & Grd-c. & Grd-b. & Grd-b. & Grd-b. & Rim & Rim & Rim & Phen. & Phen. & Cpx-trans. & Cpx-trans. \\
\hline $\mathrm{SiO}_{2}$ & 43.32 & 43.48 & 44.22 & 45.68 & 45.24 & 46.52 & 45.84 & 43.83 & 48.21 & 46.72 & 50.39 & 44.04 & 48.58 & 48.28 & 49.53 & 52.47 & 52.12 & 53.25 \\
\hline $\mathrm{TiO}_{2}$ & 1.34 & 1.43 & 0.77 & 1.08 & 1.07 & 0.44 & 0.64 & 1.21 & 0.24 & 0.28 & 0.19 & 0.76 & 0.31 & 0.35 & 0.26 & 0.16 & 0.07 & 0.04 \\
\hline $\mathrm{Al}_{2} \mathrm{O}_{3}$ & 9.65 & 9.71 & 7.64 & 8.30 & 8.12 & 7.45 & 7.33 & 9.15 & 4.73 & 6.58 & 3.80 & 8.80 & 5.37 & 5.20 & 3.69 & 2.59 & 2.81 & 2.17 \\
\hline $\mathrm{FeO}$ & 14.97 & 14.86 & 17.88 & 14.20 & 16.37 & 16.60 & 17.60 & 19.62 & 17.14 & 18.19 & 15.93 & 19.32 & 16.39 & 17.67 & 14.73 & 13.95 & 14.87 & 14.22 \\
\hline $\mathrm{MnO}$ & 0.34 & 0.33 & 0.43 & 0.33 & 0.35 & 0.32 & 0.45 & 0.38 & 0.35 & 0.35 & 0.42 & 0.39 & 0.38 & 0.38 & 0.36 & 0.42 & 0.38 & 0.29 \\
\hline $\mathrm{MgO}$ & 12.26 & 12.12 & 11.29 & 12.97 & 11.94 & 11.77 & 11.15 & 9.81 & 12.17 & 11.34 & 13.07 & 10.11 & 12.59 & 11.73 & 13.26 & 14.87 & 14.07 & 14.50 \\
\hline $\mathrm{CaO}$ & 11.68 & 11.23 & 11.36 & 11.55 & 11.48 & 12.21 & 11.72 & 11.60 & 12.27 & 11.62 & 11.63 & 11.40 & 11.65 & 11.51 & 11.24 & 11.65 & 12.05 & 12.73 \\
\hline $\mathrm{Na}_{2} \mathrm{O}$ & 2.13 & 2.32 & 1.81 & 2.00 & 2.00 & 0.81 & 1.03 & 1.27 & 0.88 & 0.99 & 0.97 & 1.23 & 0.90 & 1.21 & 1.20 & 0.92 & 0.43 & 0.23 \\
\hline $\mathrm{K}_{2} \mathrm{O}$ & 1.07 & 1.04 & 0.89 & 0.96 & 0.94 & 0.78 & 0.86 & 1.18 & 0.63 & 0.84 & 0.45 & 1.08 & 0.61 & 0.64 & 0.43 & 0.30 & 0.20 & 0.15 \\
\hline $\mathrm{F}$ & 0.78 & 0.74 & 0.38 & 0.36 & 1.01 & 0.23 & 0.27 & 0.12 & 0.34 & 0.40 & 0.34 & 0.21 & 0.00 & 0.45 & 0.22 & 0.22 & 0.00 & 0.00 \\
\hline Total & 97.53 & 97.27 & 96.67 & 97.42 & 98.51 & 97.14 & 96.90 & 98.17 & 96.97 & 97.33 & 97.19 & 97.37 & 96.78 & 97.42 & 94.92 & 97.54 & 97.00 & 97.58 \\
\hline O_F & 0.33 & 0.31 & 0.16 & 0.15 & 0.42 & 0.10 & 0.11 & 0.05 & 0.14 & 0.17 & 0.14 & 0.09 & 0.00 & 0.19 & 0.09 & 0.09 & 0.00 & 0.00 \\
\hline $\mathrm{H}_{2} \mathrm{O}$ & 1.60 & 1.62 & 1.76 & 1.82 & 1.51 & 1.88 & 1.84 & 1.91 & 1.82 & 1.78 & 1.85 & 1.85 & 0.00 & 1.77 & 1.87 & 1.94 & 0.00 & 0.00 \\
\hline $\begin{array}{l}\text { Cation } \\
\text { total }\end{array}$ & 98.80 & 98.58 & 98.27 & 99.09 & 99.60 & 98.92 & 98.62 & 100.03 & 98.65 & 98.94 & 98.90 & 99.12 & 96.78 & 99.00 & 96.70 & 99.39 & 97.00 & 97.58 \\
\hline \multicolumn{19}{|c|}{ Structural formulae based on 23 oxygens } \\
\hline$T_{\mathrm{Si}}$ & 6.52 & 6.56 & 6.72 & 6.81 & 6.77 & 6.94 & 6.90 & 6.59 & 7.23 & 7.01 & 7.47 & 6.65 & 7.22 & 7.23 & 7.49 & 7.64 & 7.62 & 7.73 \\
\hline$T_{\mathrm{Al}}$ & 1.48 & 1.44 & 1.28 & 1.20 & 1.23 & 1.06 & 1.10 & 1.41 & 0.77 & 0.99 & 0.53 & 1.35 & 0.78 & 0.77 & 0.51 & 0.36 & 0.38 & 0.27 \\
\hline$C_{\mathrm{Al}}$ & 0.23 & 0.28 & 0.09 & 0.26 & 0.20 & 0.25 & 0.20 & 0.21 & 0.07 & 0.17 & 0.13 & 0.21 & 0.16 & 0.15 & 0.15 & 0.09 & 0.11 & 0.10 \\
\hline $\mathrm{C}_{\mathrm{Fe}}^{3+}$ & 0.25 & 0.23 & 0.46 & 0.18 & 0.23 & 0.39 & 0.40 & 0.47 & 0.30 & 0.45 & 0.20 & 0.56 & 0.33 & 0.24 & 0.17 & 0.21 & 0.21 & 0.09 \\
\hline$C_{\mathrm{Ti}}$ & 0.15 & 0.16 & 0.09 & 0.12 & 0.12 & 0.05 & 0.07 & 0.14 & 0.03 & 0.03 & 0.02 & 0.09 & 0.04 & 0.04 & 0.03 & 0.02 & 0.01 & 0.00 \\
\hline$C_{\mathrm{Mg}}$ & 2.75 & 2.73 & 2.56 & 2.88 & 2.66 & 2.62 & 2.50 & 2.20 & 2.72 & 2.54 & 2.89 & 2.28 & 2.79 & 2.62 & 2.99 & 3.23 & 3.07 & 3.14 \\
\hline$C_{\mathrm{Fe}}^{2+}$ & 1.60 & 1.58 & 1.77 & 1.54 & 1.76 & 1.68 & 1.79 & 1.96 & 1.85 & 1.79 & 1.73 & 1.83 & 1.66 & 1.93 & 1.63 & 1.44 & 1.58 & 1.64 \\
\hline$C_{\mathrm{Mn}}$ & 0.02 & 0.02 & 0.03 & 0.02 & 0.02 & 0.02 & 0.03 & 0.02 & 0.03 & 0.02 & 0.03 & 0.03 & 0.02 & 0.02 & 0.02 & 0.03 & 0.02 & 0.03 \\
\hline$B_{\mathrm{Fe}}^{2+}$ & 0.03 & 0.07 & 0.04 & 0.05 & 0.05 & 0.00 & 0.02 & 0.04 & 0.00 & 0.04 & 0.05 & 0.05 & 0.04 & 0.05 & 0.06 & 0.06 & 0.03 & 0.00 \\
\hline$B_{\mathrm{Mn}}$ & 0.02 & 0.02 & 0.03 & 0.02 & 0.02 & 0.02 & 0.03 & 0.03 & 0.01 & 0.02 & 0.03 & 0.03 & 0.02 & 0.02 & 0.02 & 0.03 & 0.02 & 0.01 \\
\hline$B_{\mathrm{Ca}}$ & 1.88 & 1.81 & 1.85 & 1.84 & 1.84 & 1.95 & 1.89 & 1.87 & 1.97 & 1.87 & 1.85 & 1.84 & 1.86 & 1.85 & 1.82 & 1.82 & 1.89 & 1.98 \\
\hline$B_{\mathrm{Na}}$ & 0.06 & 0.10 & 0.08 & 0.08 & 0.09 & 0.03 & 0.06 & 0.07 & 0.02 & 0.07 & 0.08 & 0.08 & 0.08 & 0.08 & 0.10 & 0.10 & 0.06 & 0.01 \\
\hline$A_{\mathrm{Na}}$ & 0.56 & 0.58 & 0.46 & 0.50 & 0.49 & 0.21 & 0.24 & 0.30 & 0.24 & 0.22 & 0.20 & 0.28 & 0.18 & 0.27 & 0.26 & 0.16 & 0.06 & 0.05 \\
\hline$A_{\mathrm{K}}$ & 0.21 & 0.20 & 0.17 & 0.18 & 0.18 & 0.15 & 0.16 & 0.23 & 0.12 & 0.16 & 0.08 & 0.21 & 0.12 & 0.12 & 0.08 & 0.06 & 0.04 & 0.03 \\
\hline $\begin{array}{l}\text { Total } \\
\text { cations }\end{array}$ & 15.76 & 15.78 & 15.63 & 15.68 & 15.67 & 15.36 & 15.41 & 15.53 & 15.36 & 15.38 & 15.28 & 15.48 & 15.30 & 15.39 & 15.34 & 15.22 & 15.10 & 15.08 \\
\hline
\end{tabular}

Abbreviations: Inc., inclusions; Grd.-c., groundmass crystals (core); Grd-b., groundmass crystals (border); Rim, rims along clinopyroxene phenocrysts; Phen., phenocrysts; Cpx-trans., transformation of clinopyroxene phenocrysts.

zation in similar magmatic conditions, with low reequilibration with the magma. However, Mg-hornblende and actinolite grains show a general decrease of ferric and ferrous iron during crystallization and a progressive increase in $\mathrm{Mg}$. The increase in $\mathrm{Mg}$ with decreasing $\mathrm{Fe}$ in mafic minerals suggests increasing oxygen fugacity, as is confirmed by the appearance of Fe-oxides during the last magmatic stages.

Edenites are the most fluorine-rich amphiboles, with values reaching up to $1.0 \mathrm{wt} \%$ (uncorrected value), whereas the lowest F-contents (below detection limit) are obtained in actinolite amphiboles. Such concentrations are consistent with those determined by Paim et al. (2002) in the Cara Suja lamprophyres. Nearly all amphiboles, mainly the inclusions, plot in the field determined for the magmatic Ti-amphiboles (Fig. 7). Actinolites plot in the field of secondary amphiboles. The less evolved amphiboles have intermediate contents of $\mathrm{TiO}_{2}$, higher than the values found in the Cara Suja lamprophyres (Paim et al., 2002). Thus, the primary lamprophyre magma from Morro do Afonso has higher Ti contents than the Cara Suja; alterna- tively, other Ti-bearing phases were absent during crystallization of near liquidus amphiboles.

\subsection{Pyroxene}

Representative analyses of pyroxene grains appear in Table 3. All analyzed pyroxene crystals belong to the calcic series, according to the nomenclature of Morimoto (1988). Pyroxenes of the Morro do Afonso lamprophyres, as well as those of similar lamprophyre suites (Paim et al., 2002; Plá Cid et al., 2002), are diopside with very constant composition (Fig. 8). These grains are characterized by wollastonite contents of $46-49 \%$ and a more accentuated range in enstatite molecule (31-39\%).

Substitutional schemes in diopside evolution are the replacement of $\mathrm{Ca}$ by $\mathrm{Na}$ in the $\mathrm{M} 2$ site, followed by $\mathrm{MgTi} \rightarrow \mathrm{Fe}_{\text {total }}$ substitution (Fig. 9). Decrease in Ti with evolution is due to the late-magmatic crystallization of minerals such as titanite and probably mica. Neumann (1976) and Bonin and Giret (1985) describe major substitution in pyroxenes from alkaline anorogenic centers as the 
A
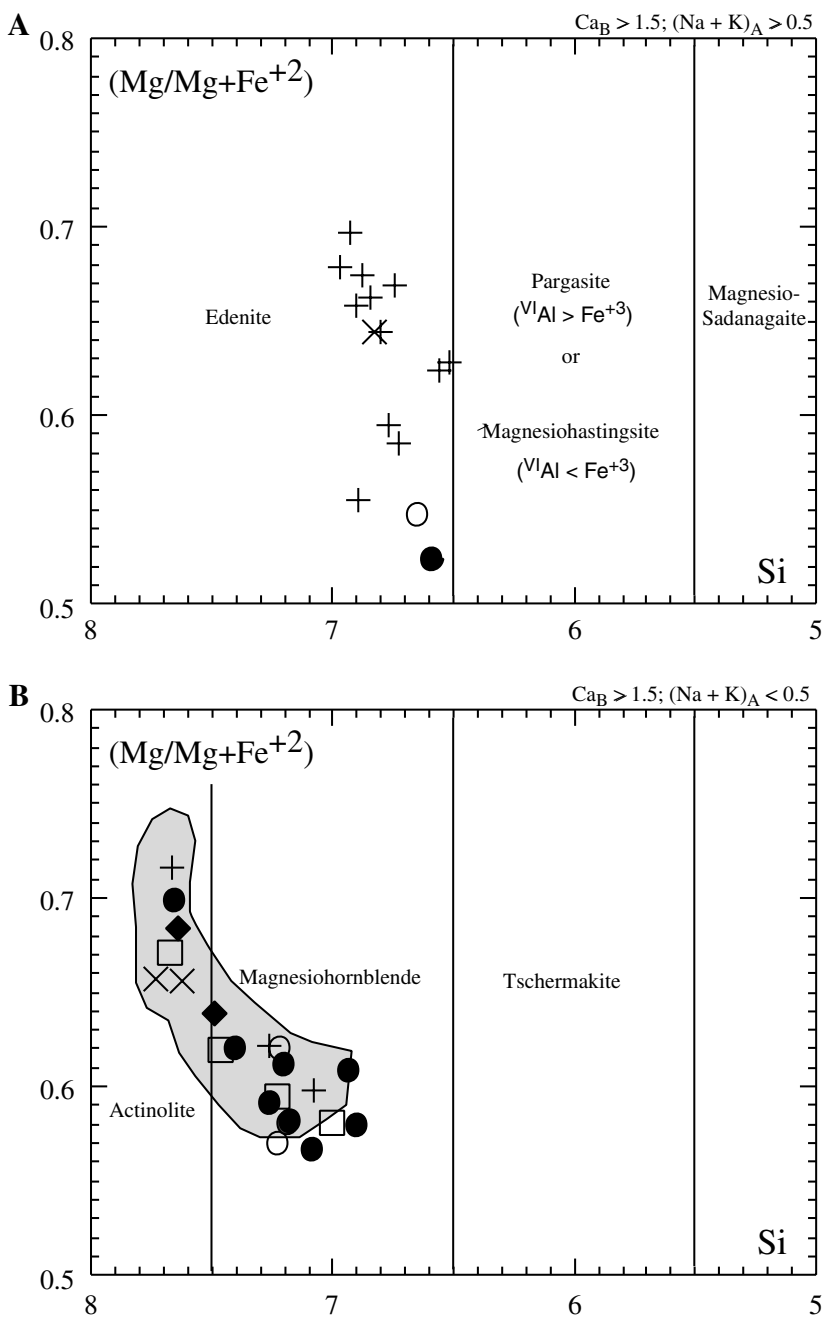

Fig. 5. Classification diagram for amphiboles (apfu) after Leake et al. (1997). Crosses, inclusions; filled circle, groundmass euhedral crystal (core); square, groundmass euhedral crystal (border); open circle, rims along clinopyroxene phenocrysts; filled diamond, phenocrysts; X, clinopyroxene alteration. Shaded area, Cara Suja lamprophyres.

replacement of $\mathrm{Ca}$ by $\mathrm{Na}$ and $\mathrm{Mg}$ by $\mathrm{Fe}$, implying an increase of the acmite molecule. According to these authors, this variation is explained by the changing $\mathrm{Fe} /$ $\mathrm{Mg}$ ratio of the magma during fractionation, and $\mathrm{Na}$ increase is related to the increase in $\mathrm{Si}$ in the magma, as well as the increase in the $\mathrm{Na} /(\mathrm{Na}+\mathrm{Ca})$ ratio. However, increasing ferric iron reflects increasing $\mathrm{fO}_{2}$ in the magma in the latest crystallization stages, as also deduced from amphibole evolution. The substitutional scheme observed in the pyroxenes from Morro do Afonso lamprophyres differs from that in Cara Suja lamprophyres (Paim et al., 2002) in the titanium behavior. It may be explained by the very low $\mathrm{TiO}_{2}$ contents $(0-0.2 \mathrm{wt} \%)$ in the Cara Suja pyroxenes versus the higher contents of the MASP $(0.1-$ $0.62 \mathrm{wt} \%)$. As described for the amphiboles, this compositional difference is probably due to the higher Ti concentrations of the parental magma from the Morro do Afonso lamprophyres.

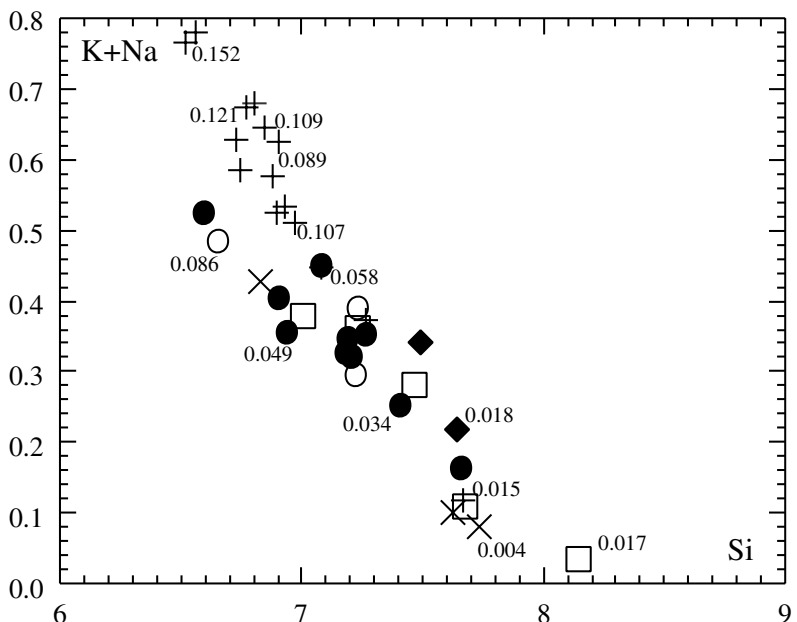

Fig. 6. $\mathrm{K}+\mathrm{Na}$ versus $\mathrm{Si}$ (apfu) diagram of amphiboles from Morro do Afonso lamprophyres. Crosses, inclusions; filled circle, groundmass euhedral crystal (core); square, groundmass euhedral crystal (border); open circle, rims along clinopyroxene phenocrysts; filled diamond, phenocrysts; $\mathrm{X}$, clinopyroxene alteration. Numbers correspond to $\mathrm{Ti}$ atoms (per formula unit) of representative analyses.

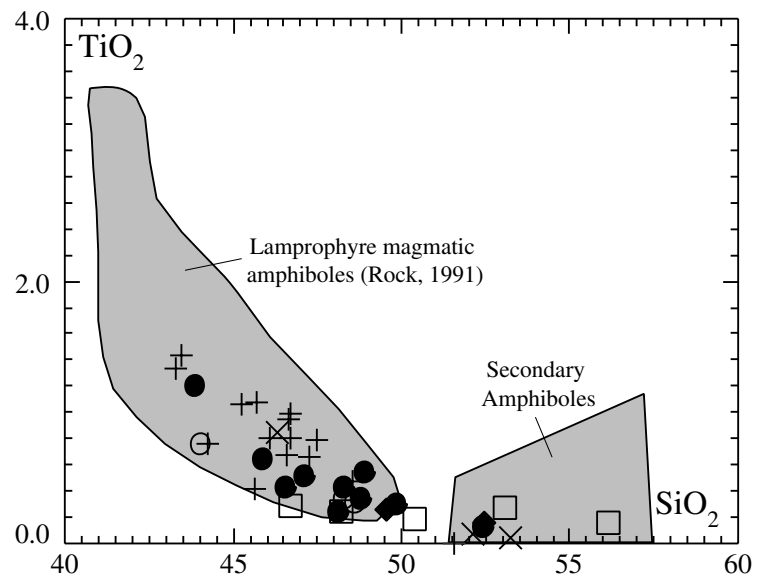

Fig. 7. $\mathrm{TiO}_{2}$ versus $\mathrm{SiO}_{2}$ diagram (wt\%) after Rock (1991) for magmatic and secondary amphiboles crystallized from lamprophyre magmas. Crosses, inclusions; filled circle, groundmass euhedral crystal (core); square, groundmass euhedral crystal (border); open circle, rims along clinopyroxene phenocrysts; filled diamond, phenocrysts; X, clinopyroxene alteration.

\section{Geochemistry}

Major and trace elements were analyzed at the LakefiedGEOSOL Consortium Laboratories by x-ray fluorescence spectrometry $[\mathrm{Si}, \mathrm{Al}, \mathrm{Fe}, \mathrm{Mg}(0.10 \%), \mathrm{Ca}, \mathrm{Ti}, \mathrm{P}, \mathrm{Mn}, \mathrm{Cl}$, $\mathrm{S}, \mathrm{Ba}, \mathrm{Cs}, \mathrm{Ga}$, Hf ( 8 ppm), Nb, Rb, Sn, Sr, Ta, Th, U (10 ppm), V (8 ppm), Y, Zr, W (10 ppm), Sc (10 ppm)] with lithium tetraborate fusion or atomic absorption $(\mathrm{Na}, \mathrm{K}$, $\mathrm{Co}, \mathrm{Cr}, \mathrm{Cu}, \mathrm{Ni}$, and $\mathrm{Pb}$ ) with multi-acid digestion ( $\mathrm{HF}$, $\mathrm{HCl}$, and percloric acid). The rare-earth elements (REE) were determined by ICP-AES spectrometry with previous concentration in ion exchange columns. Detection limits were $1 \mathrm{ppm}$ for REE, $0.01 \%$ for major elements, and 
Table 3

Representative analyses of clinopyroxenes from Morro do Afonso lamprophyres

\begin{tabular}{|c|c|c|c|c|c|c|c|c|c|c|c|c|c|c|c|c|c|}
\hline $\mathrm{SiO}_{2}$ & 52.77 & 52.88 & 52.27 & 52.57 & 52.40 & 51.27 & 50.62 & 52.10 & 53.16 & 53.09 & 52.79 & 52.99 & 53.54 & 53.26 & 53.26 & 52.72 & 52.35 \\
\hline $\mathrm{TiO}_{2}$ & 0.37 & 0.28 & 0.62 & 0.14 & 0.37 & 0.26 & 0.38 & 0.39 & 0.22 & 0.36 & 0.33 & 0.58 & 0.10 & 0.18 & 0.21 & 0.12 & 0.00 \\
\hline $\mathrm{Al}_{2} \mathrm{O}_{3}$ & 1.66 & 1.51 & 1.55 & 0.83 & 1.75 & 1.71 & 1.25 & 1.73 & 1.34 & 1.69 & 1.76 & 1.77 & 1.14 & 1.22 & 1.21 & 0.98 & 0.66 \\
\hline $\mathrm{FeO}$ & 6.83 & 7.06 & 6.99 & 10.81 & 8.57 & 10.81 & 4.00 & 5.64 & 7.79 & 7.41 & 8.19 & 7.94 & 9.45 & 9.19 & 9.41 & 9.59 & 9.85 \\
\hline $\mathrm{Fe}_{2} \mathrm{O}_{3}$ & 1.27 & 0.83 & 1.52 & 0.00 & 2.51 & 0.00 & 5.40 & 4.05 & 0.00 & 0.87 & 0.45 & 0.31 & 0.67 & 0.93 & 1.20 & 1.37 & 2.42 \\
\hline $\mathrm{MnO}$ & 0.30 & 0.44 & 0.39 & 0.46 & 0.43 & 0.51 & 0.42 & 0.42 & 0.33 & 0.39 & 0.30 & 0.29 & 0.37 & 0.36 & 0.48 & 0.41 & 0.44 \\
\hline $\mathrm{MgO}$ & 12.76 & 12.96 & 13.12 & 11.36 & 11.16 & 10.95 & 13.07 & 12.29 & 13.19 & 12.99 & 12.79 & 12.65 & 11.74 & 11.96 & 11.46 & 11.26 & 10.71 \\
\hline $\mathrm{CaO}$ & 23.50 & 23.33 & 23.24 & 22.10 & 21.35 & 20.59 & 21.87 & 22.51 & 22.41 & 22.26 & 22.14 & 22.43 & 22.84 & 22.64 & 22.42 & 22.68 & 22.39 \\
\hline $\mathrm{Na}_{2} \mathrm{O}$ & 0.74 & 0.62 & 0.52 & 1.11 & 1.45 & 1.33 & 1.11 & 1.25 & 1.11 & 0.92 & 0.79 & 0.94 & 0.89 & 0.86 & 1.01 & 0.87 & 0.97 \\
\hline Total & 100.28 & 100.00 & 100.22 & 99.38 & 99.99 & 97.43 & 98.11 & 100.38 & 99.55 & 100.02 & 99.55 & 99.91 & 100.73 & 100.63 & 100.69 & 100.03 & 99.79 \\
\hline \multicolumn{18}{|c|}{ Structural formula based on 6 oxygens } \\
\hline$T_{\mathrm{Si}}$ & 1.96 & 1.97 & 1.95 & 1.99 & 1.97 & 1.97 & 1.93 & 1.94 & 1.98 & 1.97 & 1.98 & 1.98 & 2.00 & 1.99 & 1.99 & 1.99 & 1.99 \\
\hline$T_{\mathrm{Al}}$ & 0.04 & 0.03 & 0.05 & 0.01 & 0.03 & 0.03 & 0.06 & 0.06 & 0.02 & 0.03 & 0.02 & 0.03 & 0.01 & 0.01 & 0.01 & 0.01 & 0.01 \\
\hline$T_{\mathrm{Fe}}^{3+}$ & 0.00 & 0.00 & 0.00 & 0.00 & 0.00 & 0.00 & 0.02 & 0.00 & 0.00 & 0.00 & 0.00 & 0.00 & 0.00 & 0.00 & 0.00 & 0.00 & 0.00 \\
\hline $\mathrm{M}_{\mathrm{Al}}$ & 0.03 & 0.04 & 0.02 & 0.02 & 0.05 & 0.05 & 0.00 & 0.02 & 0.04 & 0.05 & 0.05 & 0.05 & 0.05 & 0.04 & 0.04 & 0.03 & 0.02 \\
\hline $\mathrm{M} 1_{\mathrm{Ti}}$ & 0.01 & 0.01 & 0.02 & 0.00 & 0.01 & 0.01 & 0.01 & 0.01 & 0.01 & 0.01 & 0.01 & 0.02 & 0.00 & 0.01 & 0.01 & 0.00 & 0.00 \\
\hline $\mathrm{M} 1_{\mathrm{Fe}}^{3+}$ & 0.04 & 0.02 & 0.04 & 0.06 & 0.07 & 0.06 & 0.12 & 0.11 & 0.05 & 0.02 & 0.01 & 0.01 & 0.02 & 0.03 & 0.03 & 0.04 & 0.07 \\
\hline $\mathrm{M} 1_{\mathrm{Fe}+2}$ & 0.21 & 0.21 & 0.20 & 0.27 & 0.25 & 0.25 & 0.13 & 0.18 & 0.17 & 0.20 & 0.21 & 0.22 & 0.28 & 0.27 & 0.28 & 0.30 & 0.31 \\
\hline $\mathrm{M}_{\mathrm{Mg}}$ & 0.71 & 0.72 & 0.73 & 0.64 & 0.63 & 0.63 & 0.74 & 0.68 & 0.73 & 0.72 & 0.71 & 0.70 & 0.65 & 0.66 & 0.64 & 0.63 & 0.61 \\
\hline $\mathrm{M} 2_{\mathrm{Fe}}^{2+}$ & 0.00 & 0.01 & 0.02 & 0.01 & 0.02 & 0.04 & 0.01 & 0.00 & 0.02 & 0.03 & 0.05 & 0.03 & 0.01 & 0.02 & 0.01 & 0.01 & 0.00 \\
\hline $\mathrm{M} 2_{\mathrm{Mn}}$ & 0.01 & 0.01 & 0.01 & 0.02 & 0.01 & 0.02 & 0.01 & 0.01 & 0.01 & 0.01 & 0.01 & 0.01 & 0.01 & 0.01 & 0.02 & 0.01 & 0.01 \\
\hline $\mathrm{M} 2_{\mathrm{Ca}}$ & 0.94 & 0.93 & 0.93 & 0.90 & 0.86 & 0.85 & 0.89 & 0.90 & 0.89 & 0.89 & 0.89 & 0.90 & 0.91 & 0.90 & 0.90 & 0.92 & 0.91 \\
\hline $\mathrm{M} 2_{\mathrm{Na}}$ & 0.05 & 0.05 & 0.04 & 0.08 & 0.11 & 0.10 & 0.08 & 0.09 & 0.08 & 0.07 & 0.06 & 0.07 & 0.06 & 0.06 & 0.07 & 0.06 & 0.07 \\
\hline Cations & 4.00 & 4.00 & 4.00 & 4.00 & 4.00 & 4.00 & 4.00 & 4.00 & 4.00 & 4.00 & 4.00 & 4.00 & 4.00 & 4.00 & 4.00 & 4.00 & 4.00 \\
\hline
\end{tabular}

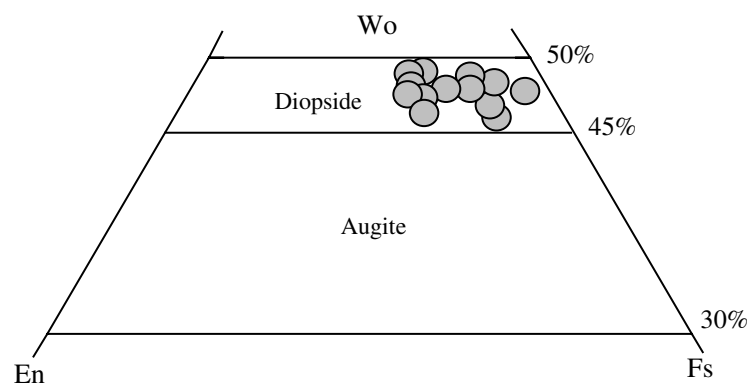

Fig. 8. Wollastonite (Wo)-enstatite (En)-ferrosilite (Fs) classification diagram (Morimoto, 1988).

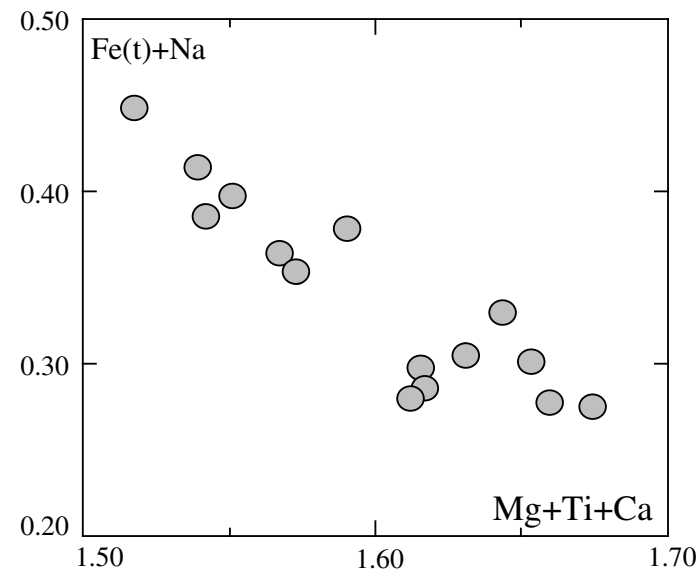

Fig. 9. Substitution scheme of clinopyroxenes from Morro do Afonso lamprophyres.
$5 \mathrm{ppm}$ for trace elements, except where a different value is indicated in brackets.

Analyses of seven samples from Morro do Afonso lamprophyres are presented in Table 4 . These lamprophyres chemically correspond to monzogabbro and monzodiorite, with slight undersaturated terms attributed to the less differentiated cumulate samples (Fig. 10). Slight silica undersaturation and saturation are typically observed in micalamprophyres (Rogers et al., 1982). In terms of alkali contents, these rocks are classified as alkaline, usually plotting in the silica-saturated alkaline field of a TAS diagram (Fig. 10) (Le Maitre et al., 1989). The $\left(\mathrm{Na}_{2} \mathrm{O}+\mathrm{K}_{2} \mathrm{O}\right) /$ $\mathrm{Al}_{2} \mathrm{O}_{3}$ Shand's index is below 1, indicating the metaluminous character of the magma. Compared with other mica-lamprophyres (Leat et al., 1988; Gibson et al., 1993; Nardi et al., submitted), Shand's index for the Morro do Afonso lamprophyres is lower, because of the lower alkali contents of magma. Sample 1317 is contaminated by alkali feldspar xenocrysts, as is reflected by the higher $\mathrm{SiO}_{2}$ concentrations (Table 4). Samples with around $44 \mathrm{wt} \%$ of $\mathrm{SiO}_{2}$ probably have a cumulate component and are not treated as a representative of the magma. All samples that represent the lamprophyre magma are classified as vogesites. Lamprophyre samples used in the petrogenetic considerations have $\mathrm{SiO}_{2}$ contents between 50 and $53 \mathrm{wt} \% . \mathrm{TiO}_{2}$ contents are low $(1-1.3 \mathrm{wt} \%)$. The higher amounts of $\mathrm{TiO}_{2}$ in the cumulate rocks reflect the presence of $\mathrm{Fe}-\mathrm{Ti}$ oxides among the accumulated minerals. $\mathrm{P}_{2} \mathrm{O}_{5}$ also behaves compatibly during fractionation, indicating the crystallization of apatite among the early magmatic minerals. The higher $\mathrm{P}_{2} \mathrm{O}_{5}$ concentrations are observed in the low silica samples as well. 
Table 4

Chemical analyses of the Morro do Afonso lamprophyres

\begin{tabular}{|c|c|c|c|c|c|c|c|}
\hline Sample & $\begin{array}{l}1322 \\
\text { minette }\end{array}$ & $\begin{array}{l}1264 \\
\text { minette }\end{array}$ & $\begin{array}{l}952 \\
\text { vogesite }\end{array}$ & $\begin{array}{l}953 \\
\text { vogesite }\end{array}$ & $\begin{array}{l}962 \\
\text { vogesite }\end{array}$ & $\begin{array}{l}1281 \\
\text { vogesite }\end{array}$ & $\begin{array}{l}1317 \\
\text { minette }\end{array}$ \\
\hline $\mathrm{SiO}_{2}$ & 44.30 & 44.50 & 50.90 & 52.00 & 52.50 & 53.40 & 63.40 \\
\hline $\mathrm{TiO}_{2}$ & 2.30 & 2.10 & 1.10 & 1.00 & 1.30 & 1.20 & 0.62 \\
\hline $\mathrm{Al}_{2} \mathrm{O}_{3}$ & 5.40 & 7.40 & 10.60 & 11.20 & 12.70 & 14.50 & 14.20 \\
\hline $\mathrm{Fe}_{2} \mathrm{O}_{3}$ & 6.70 & 5.10 & 3.60 & 4.00 & 4.00 & 4.70 & 1.60 \\
\hline $\mathrm{FeO}$ & 10.70 & 9.10 & 5.70 & 4.70 & 5.00 & 4.50 & 2.80 \\
\hline $\mathrm{MnO}$ & 0.33 & 0.29 & 0.19 & 0.18 & 0.21 & 0.15 & 0.09 \\
\hline $\mathrm{MgO}$ & 10.20 & 11.40 & 7.70 & 6.80 & 5.10 & 4.50 & 3.90 \\
\hline $\mathrm{CaO}$ & 11.80 & 12.40 & 10.30 & 9.50 & 6.90 & 5.50 & 2.80 \\
\hline $\mathrm{Na}_{2} \mathrm{O}$ & 0.64 & 1.10 & 1.10 & 1.10 & 2.60 & 3.00 & 3.20 \\
\hline $\mathrm{K}_{2} \mathrm{O}$ & 3.50 & 3.60 & 4.10 & 4.90 & 5.50 & 5.60 & 4.70 \\
\hline $\mathrm{P}_{2} \mathrm{O}_{5}$ & 2.10 & 1.80 & 1.50 & 1.50 & 1.20 & 1.10 & 0.47 \\
\hline $\mathrm{F}$ & 0.55 & 0.43 & N.D. & N.D. & N.D. & 0.24 & 0.22 \\
\hline $\mathrm{Cl}$ & 0.04 & N.D. & N.D. & N.D. & N.D. & 2.00 & 2.00 \\
\hline $\mathrm{H}_{2} \mathrm{O}^{+}$ & N.D. & 0.47 & 0.55 & 1.06 & 1.03 & N.D. & N.D. \\
\hline Total & 98.60 & 99.94 & 97.34 & 97.94 & 98.04 & 100.41 & 100.01 \\
\hline $\mathrm{Nb}$ & 21 & 19 & 11 & 16 & 31 & 12 & 5 \\
\hline $\mathrm{Y}$ & 72 & 65 & 40 & 41 & 43 & 38 & 10 \\
\hline $\mathrm{Zr}$ & 55 & 398 & 352 & 333 & 243 & 23 & 33 \\
\hline $\mathrm{Rb}$ & 148 & 149 & 89 & 115 & 175 & 145 & 161 \\
\hline $\mathrm{Sr}$ & 135 & 323 & 1838 & 2112 & 1979 & 1472 & 1410 \\
\hline $\mathrm{Ba}$ & 1827 & 2266 & 5394 & 6105 & 7140 & 2497 & 2884 \\
\hline Th & 35 & 8 & 33 & 24 & 12 & N.D. & 26 \\
\hline $\mathrm{Hf}$ & 13 & 9 & N.D. & N.D. & N.D. & N.D. & N.D. \\
\hline V & N.D. & 242 & 163 & 136 & 142 & N.D. & N.D. \\
\hline Cs & 12 & 17 & 5 & 5 & 8 & 10 & 6 \\
\hline $\mathrm{Cr}$ & N.D. & 299 & 209 & 191 & 182 & N.D. & N.D. \\
\hline Co & N.D. & 73 & 33 & 27 & 30 & N.D. & N.D. \\
\hline $\mathrm{Pb}$ & N.D. & 71 & N.D. & N.D. & N.D. & N.D. & N.D. \\
\hline $\mathrm{Ni}$ & N.D. & 125 & 86 & 70 & 97 & N.D. & N.D. \\
\hline $\mathrm{Cu}$ & N.D. & 64 & 174 & 48 & 100 & N.D. & N.D. \\
\hline $\mathrm{Ga}$ & N.D. & N.D. & 10 & 10 & 10 & N.D. & N.D. \\
\hline $\mathrm{La}$ & 277.60 & N.D. & 193.60 & 191.20 & 193.10 & 140.00 & 77.58 \\
\hline $\mathrm{Ce}$ & 582.40 & N.D. & 405.00 & 424.30 & 408.50 & 328.10 & 159.70 \\
\hline $\mathrm{Nd}$ & 223.00 & N.D. & 185.50 & 237.10 & 179.50 & 123.90 & 57.85 \\
\hline $\mathrm{Sm}$ & 37.09 & N.D. & 36.57 & 37.76 & 27.84 & 21.35 & 9.24 \\
\hline $\mathrm{Eu}$ & 4.51 & N.D. & 6.74 & 6.55 & 4.42 & 4.46 & 2.00 \\
\hline Gd & 22.22 & N.D. & 21.89 & 18.43 & 17.03 & 12.40 & 5.40 \\
\hline Dy & 10.05 & N.D. & 10.80 & 8.25 & 8.97 & 5.69 & 2.52 \\
\hline Ho & 1.61 & N.D. & 1.90 & 1.40 & 1.69 & 0.87 & 0.37 \\
\hline $\mathrm{Er}$ & 3.35 & N.D. & 3.70 & 2.51 & 4.02 & 1.90 & 0.84 \\
\hline $\mathrm{Yb}$ & 1.71 & N.D. & 1.77 & 1.08 & 2.13 & 1.11 & 0.50 \\
\hline $\mathrm{Lu}$ & 0.23 & N.D. & 0.15 & 0.12 & 0.30 & 0.17 & 0.07 \\
\hline REE Total & 1163.77 & & 867.62 & 928.70 & 847.51 & 639.94 & 316.07 \\
\hline
\end{tabular}

Abbreviation: N.D., not determined.

The CIPW normative presence of feldspars and absence of corundum and acmite confirms the metaluminous character of the original magma. In terms of silica, the Morro do Afonso lamprophyres are close to the boundary between saturated and undersaturated rocks, as is evident by the absence in most samples of both quartz and feldspathoid normative phases. Normative ilmenite and magnetite strongly decrease with differentiation from the cumulate rocks to the lamprophyres, which confirms that the $\mathrm{Fe}-\mathrm{Ti}$ phase fractionation, probably as oxides, is an effective mechanism during magmatic evolution. Normative apatite contents behave similarly to ilmenite and mag- netite, which indicates the fractionation of apatite during the early magmatic stages.

The Morro do Afonso lamprophyres have compositional characteristics typical of ultrapotassic rocks, as suggested by Foley et al. (1987). The moderate $\mathrm{MgO}$ (4.5$7.7 \mathrm{wt} \%)$ and high $\mathrm{K}_{2} \mathrm{O}(4.1-5.6 \mathrm{wt} \%)$ contents, as well as the $\mathrm{K}_{2} \mathrm{O} / \mathrm{Na}_{2} \mathrm{O}$ ratio greater than 2 , point to the ultrapotassic composition of the parental liquid. Very similar major element compositions are determined by Paim et al. (2002) in the Cara Suja minettes and by Nardi et al. (submitted) for the Piquiri minettes in southern Brazil. Both lamprophyric occurrences are associated with 


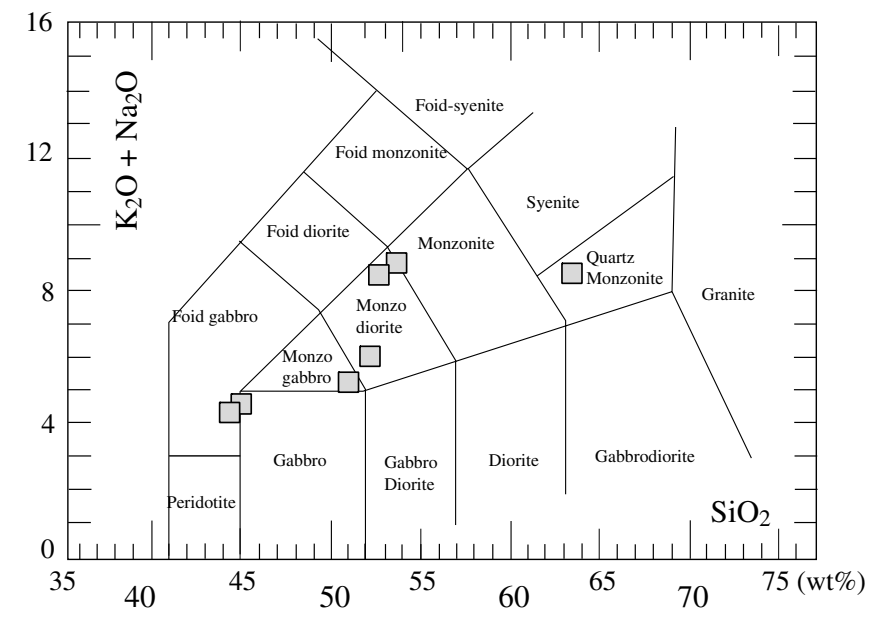

Fig. 10. Total alkali $\left(\mathrm{Na}_{2} \mathrm{O}+\mathrm{K}_{2} \mathrm{O}\right)$ versus $\mathrm{SiO}_{2}(\mathrm{wt} \%)$ diagram (Le Maitre et al., 1989), with compositional fields defined for plutonic rocks. Squares correspond to lamprophyre samples from Morro do Afonso.

syenitic intrusions. The Morro do Afonso lamprophyres are similar to the ultrapotassic group III (Foley et al., 1987), which is typically characterized by Roman Province ultrapotassic lavas and orogenic rocks. However, in the $\mathrm{CaO}$ versus $\mathrm{Al}_{2} \mathrm{O}_{3}$ diagram (Fig. 11), these lamprophyres in the field are occupied by the transitional group IV. Several occurrences of this transitional group are minettes. Major element similarity with the orogenic group III suggests that the source of these lamprophyres was probably affected by an orogenic event before the generation of parental magma. The $m g \#$ is intermediate and varies from 50 to 59 , which also is typical of micalamprophyres (Loyd et al., 1985; Esperança and Holloway, 1987; Gibson et al., 1993; Plá Cid et al., 2003).

Trace element contents of the Morro do Afonso lamprophyres show strong enrichment in volatile, $\mathrm{Ba}, \mathrm{Sr}$, and light

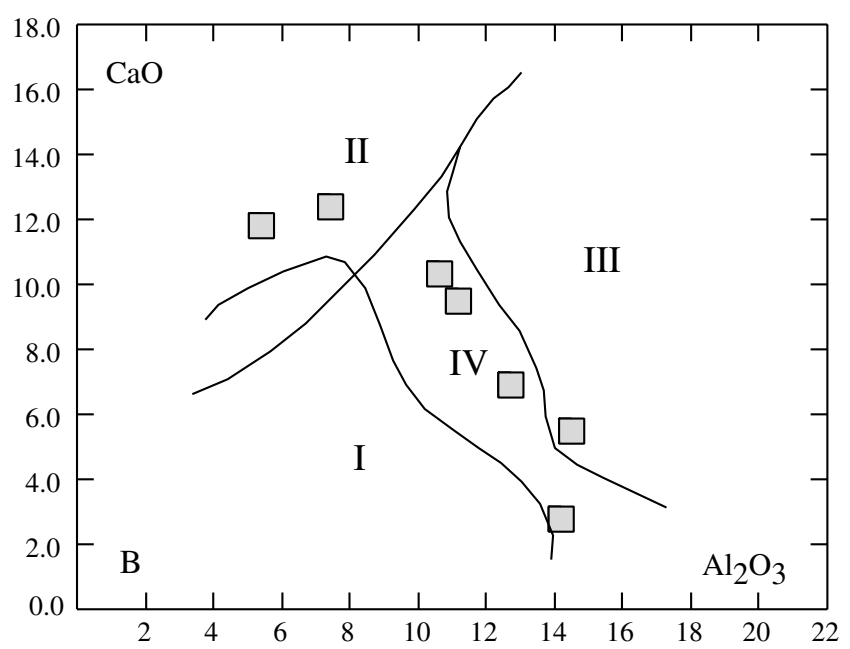

Fig. 11. Discrimination diagrams (wt $\%$ ) of Foley et al. (1987) applied to different groups of ultrapotassic rocks. rare earth elements (LREE), as well as total REE contents (Table 4). In contrast, most high field strength elements (HFSE), $\mathrm{Cr}$ and Ni present moderate to low concentrations. Large ion lithophile elements (LILE), LREE-enriched, and HFSE-depleted rocks are typical features in magmas produced by partial melting of mantle sources previously modified by metasomatic processes associated with a subducted slab (Ringwood, 1990; Foley, 1992). Harrison (1981) shows LREE-enriched liquids cannot be formed by the melting of primitive mantle, and previous LREE enrichment of the source is required. Enrichment of LILE and LREE relative to HFSE and the negative anomalies of $\mathrm{Nb}, \mathrm{Ti}$, and $\mathrm{P}$ observed in Fig. 12 are typical of subductionrelated magmas. As deduced from isotopic data (see Section 1), such subduction events and subsequent mantle source metasomatism occurred during the Archean. For comparison in these figures, we also plot the Piquiri (Plá Cid et al., 2003, 2005) and Cara Suja (Paim et al., 2002) Brazilian minettes to clarify the compositional agreement among the three suites. Plá Cid et al. (2003) discuss the metasomatic minerals that constitute the mantle source of Piquiri minettes, which may be quite similar to the source of Morro do Afonso and Cara Suja sources, as deduced from their geochemical similarity (Fig. 12). The main melted paragenesis associated with the source region of Piquiri rocks is amphibole-phlogopite-apatite-clinopyroxene( \pm garnet). $\mathrm{Zr}$ - and Sr-negative anomalies are present only in the cumulate rocks from Morro do Afonso lamprophyres, though we note a parallel with vogesites that reflects the cogenetic character of both rocks.

The REE patterns (Fig. 13) are strongly fractionated with $\mathrm{La}_{\mathrm{N}} / \mathrm{Yb}_{\mathrm{N}}$ ratios varying from 90 to 177 and discrete Eu-negative anomalies $\left(\mathrm{Eu} / \mathrm{Eu}^{*}=0.44-0.80\right)$. These patterns are similar to other minettes from Brazil (Paim et al., 2002; Nardi et al., submitted), though with greater HREE fractionation. Compared with other localities, the Morro do Afonso lamprophyres plot in the upper part of the average field defined by mica-lamprophyre compositions (Fig. 13). Rogers et al. (1982), characterizing the Navajo minettes in Arizona, demonstrate that most lamprophyre types have an $\mathrm{La} / \mathrm{Yb}$ ratio between 70 and 110 and Sm contents between 15 and $40 \mathrm{ppm}$. The Morro do Afonso lamprophyres have $\mathrm{Sm}$ concentrations in the range defined by Rogers et al. (1982), but the $\mathrm{La} / \mathrm{Yb}$ ratio can reach up to 177, indicating that LREE enrichment of the Morro do Afonso source is extreme, even for minette magmas.

\section{Petrological considerations}

\subsection{Constraints on mineral composition}

The near liquidus minerals from Morro do Afonso lamprophyres are represented by the apatite-clinopyroxeneamphibole-mica- $( \pm \mathrm{Fe}-\mathrm{Ti}$-oxides $)$ paragenesis, which is similar to that observed in other lamprophyre associations, such as the Piquiri minettes and Cara Suja intrusion. In Esperança and Holloway (1987) ('s) experimental study 


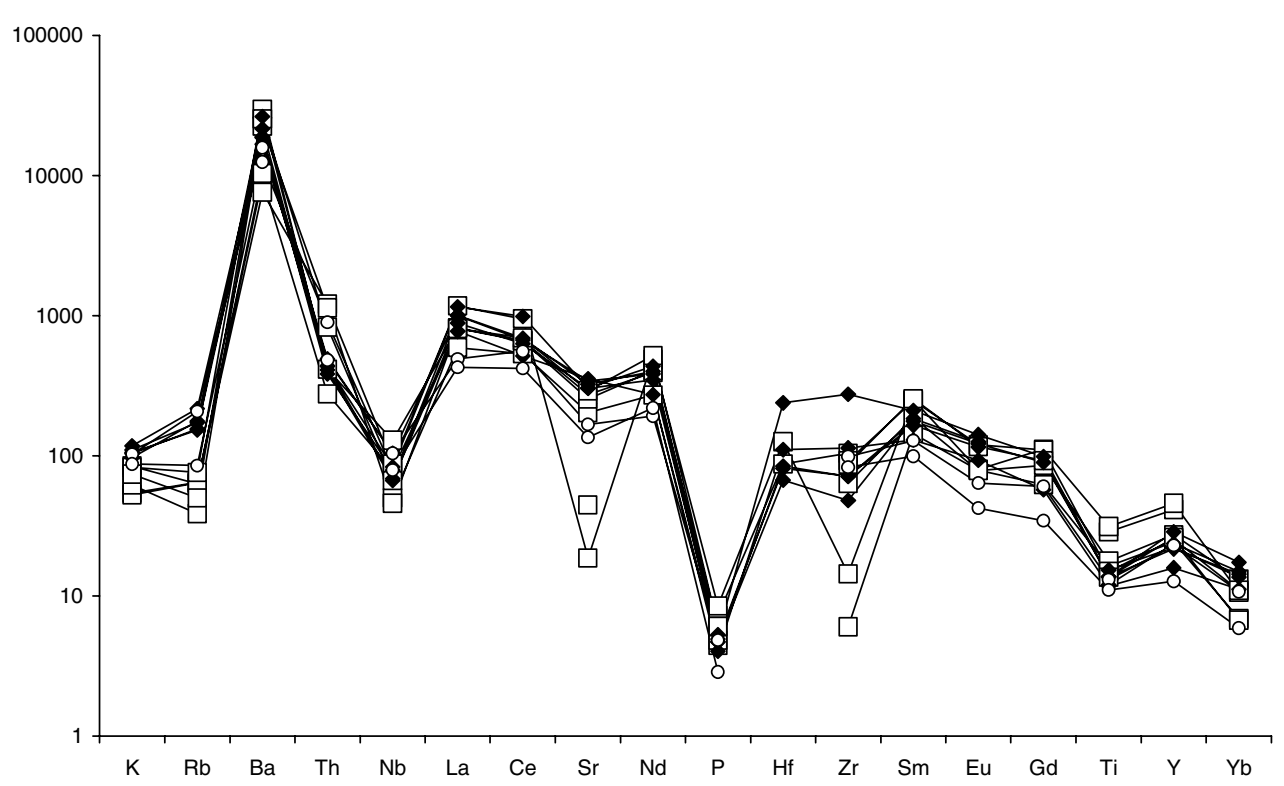

Fig. 12. Spidergram of Morro do Afonso lamprophyres, cumulate rocks, Cara Suja (Paim et al., 2002), and Piquiri (Plá Cid et al., 2003) minettes normalized to C1-chondritic values (McDonough and Sun, 1995). Squares, Morro do Afonso lamprophyres; diamonds, Piquiri minettes; circles, Cara Suja minettes.

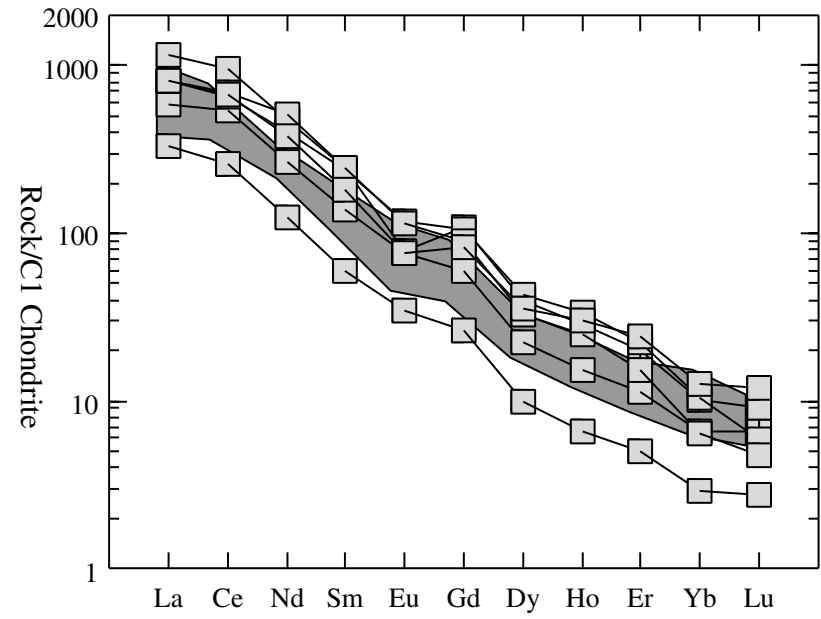

Fig. 13. REE patterns from Morro do Afonso lamprophyres normalized to chondrite values of Evensen et al. (1978). Shaded field indicates the average contents of REE of lamproite rocks considered in Table 5.

of the origin of mafic minettes, diopside, phlogopite, and olivine are among the near liquidus phases, without evidence of amphibole. These authors worked in pressure conditions below those expected by Ehrenberg (1982), Bachinski and Simpson (1984), Gibson et al. (1993), and Plá Cid et al. (2003) for the mantle region where minette magmas are produced. We recognize amphibole among the near liquidus phases of this sort of magma. Amphibole crystallization clearly is limited to the early magmatic stages, but its consequence is unknown. The presence of this phase, together with mica and apatite, demonstrates the high-volatile activity in the parental magma. Fractionation of such a paragenesis, without clinopyroxene, would produce strong silica enrichment in early magmatic stages, which may explain why clinopyroxene is always observed as crystals surrounding the partially destabilized microinclusions of amphibole. The amphibole composition observed inside the clinopyroxene may be due to magmatic reactions between near liquidus crystals with magma, when clinopyroxene starts its crystallization. A similar phenomenon was noted by Plá Cid et al. (2002) in the Piquiri minettes, where nearly all clinopyroxene phenocrysts have abundant amphibole microinclusions in the core, whereas the borders are completely amphibole-free. In the case of the Morro do Afonso lamprophyres, an original composition of the amphibole close to the stability field of undersaturated pargasite or hastingsite is suggested by the composition of the more Si-poor specimens.

Diopside is relatively homogeneous. The low amounts of $\mathrm{TiO}_{2}$ reflect the low concentrations of this element in the magma. Diopside is formed together with Fe-Ti oxides and phlogopite in the earlier magmatic stages, and other mineral phases have higher partition coefficients for titanium than diopside. The normal magmatic evolution observed in this phase is similar to mica, with progressive substitution of $\mathrm{Mg}$ by $\mathrm{Fe}^{2+}$ in the structure.

The higher amounts of fluorine in the phlogopite inclusions, compared with the other micas, indicate higher pressure-temperature conditions of crystallization and confirm its early magmatic character, according to experimental work by Foley (1991) on fluorine contents in hydrated minerals. $\mathrm{Fe}^{2+}$ and Ti are highest in the lesser-evolved samples, with $\mathrm{SiO}_{2}$ around $44 \mathrm{wt} \%$, whereas in the more differentiated rocks, the contents of $\mathrm{Fe}$ and $\mathrm{Ti}$ in mica are relatively homogeneous. Therefore, these elements are mainly retained by $\mathrm{Fe}-\mathrm{Ti}$ oxides and phlogopite, as observed by the simultaneous crystallization of both phases in the earlier magmatic stages. 
The low modal percentage of titanium-rich phases, restricted to some Fe-Ti oxide inclusions or late magmatic Fe oxides surrounded by titanite rims, is evidence of the low $\mathrm{TiO}_{2}$ contents of the original liquid. The low Ti concentration in the original magma explains the lower contents determined in mica compared with mica grains from the minettes analyzed by Bachinski and Simpson (1984). Several of their experimental studies reveal that the $\mathrm{TiO}_{2}$ contents of mica crystals from potassic melts increase with increasing oxygen fugacity, decreasing pressure, decreasing $\mathrm{H}_{2} \mathrm{O}$, and decreasing the $m g \#$ of the liquid. In mica crystals from Morro do Afonso lamprophyres, the slight Ti increase from core to border is probably due to $m g \#$ decreasing during crystallization with decreasing temperature. In the Cara Suja lamprophyres (Paim et al., 2002), despite of the similar Ti contents, oxygen fugacity seems to have been higher than in the Morro do Afonso lamprophyres, as suggested by the crystallization of Fe oxides during the latest magmatic stages.

\subsection{Constraints on geochemistry of lamprophyres}

In the literature, the minette-syenite association is considered classical. However, the Morro do Afonso lamprophyres are mainly vogesites. The main difference between these two lamprophyre types reflects the modal proportions of amphibole and mica. However, as demonstrated by the geochemical aspects of Morro do Afonso vogesites, the composition of these rocks is similar to that of minettes associated with syenites worldwide. The lower water contents of the vogesite primary magma explain the slight mineralogical differences relative to the minettes. Since the 1980 s, it has been known that minettes are formed by pulses of mafic magmas derived from metasomatized mantle. Harrison (1981) was among the first authors to propose that minettes are produced by melting of a mantle previously enriched with LREE. Thompson et al. (1989) completely discard the idea that such magmas are formed by melting of a K-rich crust, though crustal contamination may be a mechanism to explain the composition of some felsic minettes from Colorado plateau. Several doubts remain about where minettes are produced in the mantle. Garnet-lherzolite xenoliths found in the Tumb minette,
Colorado Plateau (Ehrenberg, 1979, 1982; Roden, 1982), suggest a $100-150 \mathrm{~km}$ deep source is needed for the genesis of such ultrapotassic rock. Plá Cid et al. (2003) find similar results for K-clinopyroxene and pyrope, described as among the earliest magmatic minerals of the Piquiri minettes, Brazil. Minette sources are also frequently correlated with kimberlites (Scott, 1979; Rogers et al., 1982) or lamproites (Nardi et al., submitted).

Lamprophyres from Morro do Afonso are metaluminous, alkaline, ultrapotassic rocks with slightly undersaturated to silica-saturated characters. This characteristic is typically described in minettes, though all specimens described at Morro do Afonso are vogesites. Major element composition shows low $\mathrm{TiO}_{2}$ contents, with compatible behavior, intermediate $m g \#$, and high alkalis, $\mathrm{P}_{2} \mathrm{O}_{5}$ concentrations, and $\mathrm{K}_{2} \mathrm{O} / \mathrm{Na}_{2} \mathrm{O}$ ratios. These lamprophyres are also characterized by strong enrichment in $\mathrm{Ba}, \mathrm{Sr}$, and LREE and depletion in $\mathrm{Nb}, \mathrm{Cr}, \mathrm{Ni}$, and HREE. Although some contamination by syenite magma at crustal levels affected lamprophyre (see sample 1317, Table 4), the magmatic signature seems preserved. Similar compositional characteristics are described in the literature for both minette and lamproite suites (Bergman, 1987; Leat et al., 1988; Mitchell and Bergman, 1991; Gibson et al., 1993; Paim et al., 2002; Plá Cid et al., 2003). Rios (1997) discusses the compositional similarity between the Morro do Afonso lamprophyres and lamproitic rocks. There is also a strong compositional similarity between the Morro do Afonso vogesites and the associated low-silica cumulate rocks. Such evidence suggests the cogenetic character of both rocks, as confirmed by geochemical modeling.

In Table 5, we compare the geochemical ratios of the Morro do Afonso lamprophyres with minettes and lamproites from other localities. The LILE and LREE are enriched relative to the HFSE. There is good agreement between most elemental ratios of the Morro do Afonso vogesites and minettes from the Piquiri syenite (Plá Cid et al., 2003), except for $\mathrm{Rb}$, which is lower in the studied lamprophyres. The Brazilian lamprophyres have $\mathrm{La} / \mathrm{Yb}$ ratios close to those determined in lamproites and higher than the average of minettes, which supports the LREE-enriched nature of the mantle beneath the Brazilian continental crust. Conceição et al. $(1995,2002)$ provide evidence

Table 5

Trace element ratios of lamprophyres from Morro do Afonso intrusion

\begin{tabular}{lcclccccc}
\hline Samples & 1 & 2 & 3 & 4 & 5 & 6 & 7 & 8 \\
\hline $\mathrm{Ba} / \mathrm{Y}$ & $25-166$ & $108-182$ & $92-113$ & $35-209$ & 106 & 216 & $330-390$ & $220-270$ \\
$\mathrm{Rb} / \mathrm{Nb}$ & $5.6-12$ & $16-31$ & $11-12$ & $3-11$ & 19 & 3.8 & $3.4-6$ & $2-4$ \\
$\mathrm{Ba} / \mathrm{Nb}$ & $87-400$ & $179-325$ & $59-73$ & $72-260$ & 152 & 53 & $90-144$ & $45-54$ \\
$\mathrm{La} / \mathrm{Nb}$ & $6.2-17.6$ & $9-26$ & $2.8-3.2$ & $2-6$ & 4.6 & 1.6 & $2.8-3$ & $1-3$ \\
$\mathrm{La} / \mathrm{Yb}$ & $90-176$ & $95-102$ & $84-91$ & $26-59$ & 67 & 50 & $114-191$ & $111-120$ \\
$\mathrm{La} / \mathrm{Th}$ & $5.8-16$ & $16.5-21.6$ & & & & & 1.2 \\
\end{tabular}

(1) Compared with minettes from Piquiri syenite (2, Nardi et al., submitted); SW Tibet (3, Miller et al., 1999); Rio Grande rift (4, Gibson et al., 1993); Bahia, Brazil (5, Paim et al., 2002); lamproites from Spain (6, Bergman, 1987); Leucite Hill (7, Bergman, 1987; Mitchell, 1995); Gaussberg, Antarctica (8, Murphy et al., 2002), and Peru (9, Carlier and Lorand, 1997). 
that a LILE- and LREE-enriched mantle source produced the syenitic and lamprophyric magmatism in the Serrinha nucleus.

Geochemical composition of the syenites and lamprophyres agrees with a mantle source previously modified by interaction with fluids/melts of a subducted oceanic slab. The isotopic data obtained in the Morro do Afonso, as well as other potassic and shoshonitic intrusions in Serrinha (Rios, 2002) and Guanambi (Rosa, 1999) nuclei, suggest that these $T_{\mathrm{DM}^{-}}$-age $(2.56-2.58 \mathrm{Ga})$ represent the extraction age of the primary melts from a metasomatized mantle affected by a subducted slab in a collisional setting before the Paleoproterozoic. Although the source of this magmatism is probably correlated with an older subduction, the main metamorphic event in the basement rocks in the Serrinha nucleus is dated at $2.1 \mathrm{Ga}$, and paleoproterozoic calc-alkaline rocks are associated with juvenile magmas with similar chemical signature to felsic rocks from the Itapicuru greenstone belt, which suggests a second collisional event during the Paleoproterozoic, close to the crystallization age determined for the MASP. However, such a collision could not be responsible for the hybridization of the mantle source of syenites and lamprophyres from Morro do Afonso, and its role in the uprising of these magmas remains unknown.

Several authors (Leat et al., 1988; Janasi et al., 1993; Conceição et al., 1995) argue that minette liquids could produce syenite magmas by crystal fractionation. Plá Cid et al. (2005) show that crystal fractionation from a minette magma is not a petrogenetic mechanism capable of explaining the composition of the associated ultrapotassic Piquiri syenite. Therefore, this syenite is formed by several facies, or different magmas, and only the diopside-phlogopite syenite might be genetically related to the minette magma by fractionation. To test the possible genetic relationship between lamprophyres and syenites in the Morro do Afonso intrusion, we use GENESIS software, version 2.0 (Teixeira, 1996), to model the major element evolution of a fractionating lamprophyre magma (Table 6).

The lamprophyres, as detailed previously, include among their early magmatic minerals diopside, phlogopite, amphibole, ilmenite, and apatite. The chemical composition of mafic silicates we use in the modeling is that presented previously. Analyses of apatite from Cara Suja

Table 6

Major element modeling of lamprophyres and syenites from Morro do Afonso intrusion

\begin{tabular}{|c|c|c|c|c|}
\hline & Co (952) & Syenite (939) & Liquid-calculated & Solid \\
\hline \multicolumn{5}{|c|}{ Vogesite-mesocratic syenite (deviation 1.489 and $F 40 \%$ ) } \\
\hline $\mathrm{SiO}_{2}$ & 52.35 & 56.16 & 56.26 & Cpx- 28.44 \\
\hline $\mathrm{TiO}_{2}$ & 1.13 & 0.91 & 1.26 & Amp- 58.34 \\
\hline $\mathrm{Fe}_{2} \mathrm{O}_{3}$ & 10.21 & 8.34 & 8.44 & Ilm- 0.85 \\
\hline $\mathrm{MgO}$ & 7.92 & 5.09 & 5.08 & Ap- 5.48 \\
\hline $\mathrm{CaO}$ & 10.59 & 5.60 & 6.07 & \\
\hline \multirow[t]{2}{*}{$\mathrm{P}_{2} \mathrm{O}_{5}$} & 1.54 & 0.92 & 0.93 & \\
\hline & Syenite (939) & Syenite (932) & & \\
\hline \multicolumn{5}{|c|}{ Mesocratic syenite-Leucocratic syenite (deviation 1.09 and $F 20 \%$ ) } \\
\hline $\mathrm{SiO}_{2}$ & 56.16 & 59.81 & 59.10 & Cpx- 48.03 \\
\hline $\mathrm{TiO}_{2}$ & 0.91 & 0.88 & 0.90 & Phl- 49.20 \\
\hline $\mathrm{Na}_{2} \mathrm{O}$ & 3.15 & 4.48 & 3.77 & \\
\hline $\mathrm{K}_{2} \mathrm{O}$ & 6.51 & 6.11 & 6.89 & \\
\hline \multirow[t]{2}{*}{$\mathrm{P}_{2} \mathrm{O}_{5}$} & 0.92 & 0.48 & 0.83 & \\
\hline & Solid & Cumulate (1264) & & \\
\hline \multicolumn{5}{|c|}{ Calculated solid compared with low-silica cumulate } \\
\hline $\mathrm{SiO}_{2}$ & 44.41 & 44.50 & & \\
\hline $\mathrm{TiO}_{2}$ & 0.95 & 2.10 & & \\
\hline $\mathrm{Al}_{2} \mathrm{O}_{3}$ & 7.81 & 7.40 & & \\
\hline $\mathrm{Fe}_{2} \mathrm{O}_{3}$ & 16.15 & 15.10 & & \\
\hline $\mathrm{MgO}$ & 11.99 & 11.40 & & \\
\hline $\mathrm{CaO}$ & 11.74 & 12.40 & & \\
\hline $\mathrm{Na}_{2} \mathrm{O}$ & 0.69 & 1.10 & & \\
\hline
\end{tabular}

The samples are recalculated to $100 \mathrm{wt} \% . F$ corresponds to the percentage of fractionated solid. 
lamprophyres (M.M. Paim, pers. comm.) and ilmenite from Estreito ultrapotassic syenite, western Bahia (Rosa, 1999) also are used in the modeling. To model different facies of syenitic rocks, we use clinopyroxene and mica composition obtained from similar syenites from Bahia. We use the least evolved sample of lamprophyre (952) and samples with different silica saturation from the syenite intrusion (Table 6) to explain the fractionation mechanism.

The chemical variation of different samples of lamprophyres is explained by fractionation of amphibole + apatite, with a produced deviation value of 0.515 . Clinopyroxene was also tested as a fractionating phase, though the result is better for the paragenesis amphiboleapatite only. The results show that by fractionating some early magmatic phases (less than $10 \%$ of solid) from the lamprophyre magma, it is possible to explain the internal geochemical variation of the lamprophyric rocks. Phlogopite was not present among the fractionated phases. Lamprophyres and mesocratic syenites are genetically related, as deduced from fractionation modeling, which shows that lamprophyre magma may produce syenitic rocks with lower silica contents (Table 6) by fractionating the assumed early magmatic minerals. The assumed solid percentage is between 30 and $40 \%$. The composition of this cumulate rock is probably ultramafic, with a higher amount of amphibole relative to clinopyroxene. We performed a second type of modeling to test the possible mechanism of petrogenetic evolution from low-silica syenites $(56 \mathrm{wt} \%)$ to intermediate syenites $(59 \mathrm{wt} \%)$. Fractionation of clinopyroxene-mica-apatite promotes this petrogenetic evolution. The composition of the fractionated solid is similar to that of rocks interpreted as cumulates $\left(\mathrm{SiO}_{2}, 44 \mathrm{wt} \%\right)$ and assumed to have minette composition. It is therefore possible to explain the generation of the cumulate rocks with a mineral composition similar to those of the minettes by fractionation of the mesocratic syenite magmas. The low deviations indicate that such a mechanism is a plausible explanation of the lamprophyre-syenite link in the MASP and suggest that only one lamprophyre parental magma, with vogesite composition, was present.

\section{Conclusions}

The crystallization order of the Morro do Afonso lamprophyres shows near liquidus paragenesis composed of phlogopite-diopside-edenite-apatite-( $\pm \mathrm{Fe}-\mathrm{Ti}$-oxide $)$. During crystallization, phlogopite evolves to $\mathrm{Mg}$-biotite and low-silica edenite to Mg-hornblende. Mineral chemistry of clinopyroxene and amphibole indicates a slight increase of oxygen fugacity in the late magmatic stages. Crystallization of late magmatic Fe-oxides supports this hypothesis. Mica crystals from Morro do Afonso lamprophyres, as well as those of minettes from other Brazilian localities, plot along the boundary between alkaline and calc-alkaline magmatic rocks. Although additional studies on this subject are necessary, mica grains of ultrapotassic lamp- rophyre magmas also may plot in this compositional region.

Morro do Afonso lamprophyres are alkaline, metaluminous, and ultrapotassic rocks, with a mineralogical composition compatible to that of vogesites. These rocks are Paleoproterozoic in age (Rios, 2002), and field relationships demonstrate that the lamprophyre and syenite magmas coexisted. The vogesites crystallized from a magma extremely enriched in LILE and LREE and relatively depleted in HFSE, Cr, and Ni. Such characteristics exclude a typical peridotitic mantle source. The enrichment in trace elements such as $\mathrm{K}, \mathrm{Ba}, \mathrm{Sr}, \mathrm{Cs}, \mathrm{La}, \mathrm{Ce}$, and $\mathrm{Nd}$ is typically observed in magmas produced by partial melting of a metasomatized mantle source. The lamprophyres exhibit trace-element patterns similar to those of active continental margins basalts. Several trace element ratios are close to those observed in minettes and lamproites, suggesting that the source of these vogesites may have a similar composition. Their composition is also very similar to minettes found in association with syenites in different parts of Brazil.

Major element modeling shows that crystal fractionation and accumulation, by flow segregation, are two petrogenetic processes associated with the evolution of the lamprophyric and syenitic rocks of Morro do Afonso. Amphibole + apatite segregation explains internal differentiation in the lamprophyre magma. Amphibole-clinopyroxene-mica-apatite-ilmenite paragenesis probably was fractionated and generated the mesocratic syenitic rocks from the lamprophyre magma. Evolution from mesocratic syenites to intermediate syenites is characterized by the formation of cumulates of clinopyroxene-mica-apatite. Mineralogical composition of these cumulates is typical of minettes. The calculated chemical composition of cumulates is close to that of cumulate rocks found in the MASP.

Phlogopite is the near liquidus mica crystallized from worldwide vogesites. The mica crystals at Morro do Afonso have low contents of $\mathrm{TiO}_{2}$ relative to worldwide minettes. This feature is also observed in the Cara Suja minettes and similar to that of calc-alkaline and alkaline rocks. The chemical evolution of these micas is marked by the substitution $\mathrm{Mg}+{ }^{\mathrm{VI}} \mathrm{Al} \rightarrow \mathrm{Fe}^{2+}+\mathrm{Ti}$ and $\mathrm{Si} \rightarrow{ }^{\mathrm{IV}} \mathrm{Al}$. $\mathrm{Fe}$ and $\mathrm{Ti}$ incorporation is supported by the crystallization of $\mathrm{Fe}$ oxide and titanite in the later magmatic stages.

Amphibole has a wide compositional range; near-liquidus crystals are low-silica edenite, but Mg-hornblende and actinolite are also present. This evolution is similar to that of minettes associated with the Cara Suja and Piquiri syenites. Ti contents are lower in late magmatic actinolite, reflecting simultaneous crystallization of $\mathrm{Ti}$ bearing phases, such as titanite. Fe concentrations progressively decrease during amphibole evolution, and increase of Mg-contents is observed.

Clinopyroxene crystals are diopside with homogeneous composition. Substitutional schemes involve replacement of $\mathrm{Ca}$ by $\mathrm{Na}$, as well as the relation $(\mathrm{Mg}+\mathrm{Ti}) \rightarrow \mathrm{Fe}_{\text {total }}$. Such evolution is evidence of an increase in the acmite 
component, suggesting that progressive enrichment of sili$\mathrm{ca}$ in magma aids the incorporation of $\mathrm{Na}$ in the pyroxene structure. The enrichment in the acmite molecule is additional evidence that lamprophyre evolution is marked by an increase in $\mathrm{fO}_{2}$-conditions.

\section{Acknowledgements}

The authors thank Conselho Nacional de Desenvolvimento Científico e Tecnológico-CNPq (Proc. 150288/ 2003-4; 350349/2004-5), PRODOC-FAPESB/CNPq, Xavier Llovet from Serveis Cientificotècnics (Universitat de Barcelona, Spain), and two anonymous reviewers.

\section{References}

Abdel-Rahman, A.M., 1993. Nature of biotites from alkaline, calcalkaline, and peraluminous magmas. J. Petrol. 35 (2), 525-541.

Ayrton, S., 1991. The zonation of granitic plutons: the "failed ring-dyke" hypothesis. Schwei. Mineral. Petrog. 68, 1-19.

Bachinski, S.W., Simpson, E.L., 1984. Ti-phlogopites of the Shaw's Cove minette: a comparison with micas of other lamprophyres, potassic rocks, kimberlites, and mantle xenoliths. Am. Mineral. 69, 41-56.

Barnes, R.P., Rock, N.M.S., Gaskarth, J.W., 1986. Late Caledonian dykeswarm in southern Scotland: new field, petrological and geochemical data for the Wigtown Peninsula, Galloway. Geol. J. 21, 101-125.

Bergman, S.C., 1987. Lamproites and other potassium-rich igneous rocks: a review of their occurrence, mineralogy and geochemistry. In: Fitton, J.G., Upton, B.G.J. (Eds.), Alkaline Igneous Rocks. Geological Society of London, Special Publications, pp. 103-189.

Boetcher, A.L., O'Neil, J.R., Windom, K.E., Stewart, D.C., Wilshire, H.G., 1977. Metasomatism and the genesis of kimberlites and alkali basalts. In: Proceedings of the Second International Kimberlite Conference (Extended Abstracts).

Bonin, B., Giret, A., 1985. Clinopyroxene compositional trend in oversaturated and undersaturated alkaline ring complexes. J. Afr. Earth Sci. 3, 175-183.

Carlier, G., Lorand, J.P., 1997. First occurrence of diopside-sanidinephlogopite lamproite in the Andean Cordillera: the Huacancha and Morojarja dikes, southern Peru. Can. J. Earth Sci. 34, 1118-1127.

Carmichael, I.S.E., 1967. The mineralogy and petrology of the volcanic rocks from the Leucite Hills, Wyoming. Contrib. Mineral. Petrol. 15, 24-66.

Chazot, G., Menzies, M., Harte, B., 1996. Determination of partition coefficients between apatite, clinopyroxene, amphibole, and melt in natural spinel lherzolites from Yemen: implications for wet melting of the lithospheric mantle. Geochim. Cosmochim. Acta 60, 423-437.

Conceição, H., 1990. Petrologie du Massif Syénitique d'Itiúba: contribution a l'etude minéralogique dês roches alcalines dans l'Etat de Bahia (Brésil): thèse Doctorat, Université Paris-Sud, Centre d'Orsay, p. 395.

Conceição, H., 1993. Petrology of the Syenites from Salvador-Curaçá Mobile Belt (Bahia-Brazil): geodynamic significance. Anais da Academia Brasileira de Ciências 65, 17-32.

Conceição, H., Rios, D.C., Rosa, M.L.S., 1995. Petrologia da Associação Sienito-Lamprófiro: Caso da Intrusão de Morro do Afonso (Greenstone Belt do Rio Itapicuru, Bahia). Geochim. Brasiliensis 9, 91-109.

Conceição, H., Gusmão, C.M.B., Rios, D.C., Rosa, M.L.S., Cruz Filho, B.E., Peixoto, A.A., Oliveira, L.L., Marinho, M.M., Macambira, M.J.B., Scheller, T., 2000. Stocks de K-sienitos pós-orogênicos com assinatura de subducção e afinidade lamprofírica na parte sudoeste do Núcleo Serrinha (Estado da Bahia): petrografia, idade e litogeoqúmica. Geochim. Brasiliensis 14 (1).

Conceição, H., Rios, D.C., Rosa, M.L.S., Davis, D.W., Dickin, A.P., McReath, I., Marinho, M.M., Macambira, M.J.B., 2002. Zircon geochronology and petrology of alkaline-potassic syenites, Southwest- ern Serrinha Nucleus, East São Francisco Craton, Brazil. Int. Geol. Rev. 44, 117-136.

Dropp, G.T.R., 1987. A general equation for estimating $\mathrm{Fe}^{3+}$ concentrations in ferromagnesian silicates and oxides from microprobe analyses using stoichiometric criteria. Mineral. Mag. 51, 431-435.

Ehrenberg, S.N., 1979. Garnetiferous ultramafic inclusions in minette from the Navajo volcanic field. In: Boyd, F.R., Meyer, H.O.D. (Eds.), The Mantle Sample: Inclusions in Kimberlite and Other Volcanics. American Geophysical Union, p. 330.

Ehrenberg, S.N., 1982. Rare earth element geochemistry of garnet lherzolite and megacrystalline nodules from minette of the Colorado Plateau province. Earth Planet. Sci. Lett. 57, 191-210.

Esperança, S., Holloway, J.R., 1987. On the origin of some micalamprophyres: experimental evidence from a mafic minette. Contrib. Mineral. Petrol. 95, 207-216.

Evensen, N.M., Hamilton, P.J., O’Nions, R.K., 1978. Rare earth abundance in chondritic meteorites. Geochim. Cosmochim. Acta 42, $1199-1212$.

Foley, S., 1991. High-pressure stability of the fluor- and hydroxyendmembers of pargasite and K-richterite. Geochim. Cosmochim. Acta 55, 2689-2694.

Foley, S., 1992. Petrological characterization of the source components of potassic magmas: geochemical and experimental constraints. Lithos 28, 187-204.

Foley, S., Venturelli, G., Green, D.H., Toscani, L., 1987. The ultrapotassic rocks: characteristics, classification, and constraints for petrogenetic models. Earth Sci. Rev. 24, 81-134.

Gibson, A.S., Thompson, R.N., Leat, P.T., Morrison, M.A., Hendry, G.L., Dickin, A.P., Mitchell, J.G., 1993. Ultrapotassic magmas along the flanks of the Oligo-Miocene Rio Grande Rift, USA: monitors of the zone of lithospheric mantle extension and thinning beneath a continental rift. J. Petrol. 34, 87-228.

Gibson, A.S., Thompson, R.N., Dickin, A.P., Leonardos, O.H., 1995. High-Ti and low-Ti mafic potassic magmas: key to plume-lithosphere interactions and continental flood-basalt genesis. Earth Planet. Sci. Lett. 136, 149-165.

Giret, A., Bonin, B., Leger, J.M., 1980. Amphibole compositional trends in oversaturated and undersaturated alkaline plutonic ring complexes. Can. Mineral. 18, 481-495.

Harrison, W.J., 1981. Partitioning of REE between minerals and coexisting melts during partial melting of a garnet lherzolite. Am. Mineral. 66, 242-259.

Hofmann, A.W., White, W.M., 1980. The role of subducted oceanic crust in mantle evolution. Carnegie Inst. Wash. Yearbook 79, 477-483.

Janasi, V.A., Vlach, S.R.F., Ulbrich, H.H.G.J., 1993. Enriched-mantle contributions to the Itu granitoid belt, southeastern Brazil: evidence from K-rich diorites and syenites. Anais da Acadêmia Brasileira de Ciências 65, 107-118.

Jones, A.P., Smith, J.V., Dawson, J.B., 1982. Mantle metasomatism in 14 vein peridotites from Bultfontein Mine, South Africa. J. Geol. 90, 435453.

Kesson, S.E., Ringwood, A.E., 1989. Slab-mantle interactions. 1. Sheared garnet peridotite xenoliths - examples of Wadati-Benioff zones? Chem. Geol. 78, 83-96.

Kramer, W., 1976. Genese der lamprophyre im Bereich der Fichtelgebirgisch-Erzgebirgischen Antiklinalzone. Chemie der Erde 35, 149.

Leake, B.E., Wooley, A.R., Arps, C.E.S., Birch, W.D., Gilbert, M.C., Grice, J.D., Hawthorne, F.C., Kato, A., Kisch, H.J., Krivovichev, V.G., Linthout, K., Laird, J., Mandarino, J.Á., Maresch, W.V., Nickel, E.H., Rock, N.M.S., Schumacher, J.C., Smith, D.C., Stephenson, N.C.N., Ungaretti, L., Whittaker, E.J.W., Youzhi, G., 1997. Nomenclature of amphiboles: report of the Subcommittee on Amphiboles of the International Mineralogical Association, Commission on New Minerals and Mineral Names. Am. Mineral. 82, 10191037.

Leat, P.T., Thompson, R.N., Morrison, M.A., Hendry, G.L., Dickin, A.P., 1988. Silicic magmas derived by fractional crystallization from 
Miocene minette, Elkhead Mountains, Colorado. Mineral. Mag. 52, 577-585.

Le Maitre, R.W., Bateman, P., Dubek, A., Keller, J., Lameyre, J., Le Bas, M.J., Sabine, P.A., Schimid, R., Sorensen, H., Streckeisen, A., Wooley, A.R., Zanettin, B., 1989. In: Le Maitre, R.W. (Ed.), A Classification of Igneous Rocks and Glossary of Terms: Recommendations of the International Union of Geological Sciences Subcommission on the Systematics of Igneous Rocks. Londres, Blackwell, Oxford, UK, p. 193.

Loyd, F.E., Arima, M., Edgar, A.D., 1985. Partial melting of a phlogopite cliopyroxenite nodule from south-west Uganda: an experimental study bearing on the origin of highly potassic continental rift volcanics. Contrib. Mineral. Petrol. 91, 321-329.

Luhr, J.F., Carmichael, I.S.E., 1981. The Colima volcanic complex, Mexico: Part II. Late-quaternary cinder cones. Contrib. Mineral. Petrol. 76, 127-147.

Mascarenhas, J.F., 1979. Evolução geotectônica do Pré-Cambriano do Estado da Bahia. Geologia e Recursos Minerais do Estado da Bahia. Textos Básicos. Secretaria de Minas e Energia (Salvador, Bahia) 2, 57165.

Matos, F.M.V., Conceição, H., 1993. Granitogênese associada à parte oeste do Cráton Serrinha e o Greenstone Belt do Rio Itapicuru: Geologia e Tipologia. Segundo Simpósio do Cráton do São Francisco. SBG/SGM/CNPq, Núcleo Bahia-Sergipe, Salvador, pp. $60-62$.

McCulloch, M.T., Jaques, A.L., Nelson, D.R., Lewis, J.D., 1983. Nd and $\mathrm{Sr}$ isotopes in kimberlites and lamproites from Western Australia: an enriched mantle origin. Nature 302, 400-403.

McDonough, W.F., Sun, S.-S., 1995. The composition of the Earth. Chem. Geol. 120, 223-253.

McKenzie, D., 1989. Some remarks of the movement of small melt fractions in the mantle. Earth Planet. Sci. Lett. 95, 53-72.

Métais, D., Ravier, J., Duong, P.K., 1962. Nature et composition chimique des micas de deux lamprophyres. Bulletin de la Societé Française de Mineralogie et Cristallographie 85, 321-328.

Miller, C., Schuster, R., Klotzli, U., Frank, W., Purtscheller, F., 1999. Post-collisional potassic and ultrapotassic magmatism in SW Tibet: geochemical and $\mathrm{Sr}-\mathrm{Nd}-\mathrm{Pb}-\mathrm{O}$ isotopic constraints for mantle source characteristics and petrogenesis. J. Petrol. 40, 1399-1424.

Mitchell, R.H., 1995. Melting experiments on a sanidine phlogopite lamproite at 4-7 GPa and their bearing on the sources of lamproitic magmas. J. Petrol. 36, 1455-1470.

Mitchell, R.H., Bergman, S.C., 1991. Petrology of Lamproites. Plenum Press, New York, USA (p. 447).

Morimoto, C.N., 1988. Nomenclature of pyroxenes. Mineral. Mag. 52, 535-550.

Murphy, D.T., Collerson, K.D., Kamber, B.S., 2002. Lamproites from Gausberg, Antártica: posible transition zone melts of Archaean subducted sediments. J. Petrol. 43, 981-1001.

Nardi, L.V.S., Plá Cid, J., Bitencourt, M.F., submitted. Geochemistry of minettic mafic microgranular enclaves in lamprophyre-syenite systems formed at mantle pressures. Lithos.

Nemec, D., 1968. Fluorine in lamprophyres and lamproitic rocks. Geochim. Cosmochim. Acta 32, 523-529.

Neumann, E.R., 1976. Compositional relations among pyroxenes, amphiboles and other mafic phases in the Oslo region plutonic rocks. Lithos 9, 85-109.

Paim, M.M., Plá Cid, J., Rosa, M.L.S., Conceição, H., Nardi, L.V.S., 2002. Mineralogy of lamprophyres and mafic enclaves associated to the Paleoproterozoic Cara Suja Syenite, NE Brazil. Int. Geol. Rev. 44, $1017-1036$

Plá Cid, J., Nardi, L.V.S., Enrique, P., 2002. Textural relations of lamprophyric mafic microgranular enclaves and petrological implications for the genesis of potassic syenitic magmas: the example of Piquiri Syenite, southern Brazil. Pesquisas em Geociências 29, $21-30$.
PláCid, J., Nardi, L.V.S., Conceição, R.V., Stabel, L.Z., Balzaretti, N.M., 2003. K-clinopyroxene, pyrope-rich garnet, and potassian pargasite from mafic microgranular enclaves of Piquirí Syenite, southernmost Brazil: evidences of syenitic and minettic magma mingling at upper mantle pressures. Contrib. Mineral. Petrol. 145, 444-459.

Plá Cid, J., Nardi, L.V.S., Enrique, P., Merlet, C., Boyer, B., 2005. SIMS analyses on trace and rare earth elements in coexisting clinopyroxene and mica from minette mafic enclaves in potassic syenites crystallized under high pressures. Contrib. Mineral. Petrol. 148, 675-688.

Rieder, M., Cavazzini, G., D’Yakonov, Y.S., Frank-Kamenetskii, V.A., Gottardi, G., Guggenheim, S., Koval, P.V., Muller, G., Neiva, A.M.R., Radoslovich, E.W., Robert, J.-L., Sassi, F.P., Takeda, H., Weiss, Z., Wones, D.R., 1998. Nomenclature of micas. Can. Mineral. 36, 905.

Ringwood, A.E., 1982. Phase transformations and differentiation in subducted lithosphere: implications for mantle dynamic basalt petrogenesis and crustal evolution. J. Geol. 90, 611-643.

Ringwood, A.E., 1990. Slab-mantle interactions. 3. Petrogenesis of intraplate magmas and structure of the upper mantle. Chem. Geol. 82, 187-207.

Rios, D.C., 1997. Petrologia do magmatismo potássico-ultrapotássico e lamprofírico de Morro do Afonso-Bahia. M.Sc. Thesis. CPGGUFBA, Salvador, Brazil, p. 237.

Rios, D.C., 2002. Granitogênese no núcleo Serrinha, Bahia, Brasil: Geocronologia e Liteogeoquímica. Doctoral Thesis. CPGG-UFBA, Salvador, Brazil, p. 239.

Rock, N.M.S., 1987. The nature and origin of lamprophyres: an overview. In: Fitton, J.G., Upton, B.G.J. (Eds.), Alkaline Igneous Rocks. Geological Society of London, Special Publications 30, 191-226.

Rock, N.M.S., 1991. Lamprophyres. Blackie-Van Norstrand Reinhold, New York, USA, p. 285.

Roden, M.F., 1982. Origin of coexisting minette and ultramafic breccia, Navajo volcanic field. Contrib. Mineral. Petrol. 77, 195-206.

Rogers, N.W., Bachinski, S.W., Henderson, P., Parry, S.J., 1982. Origin of potassic-rich basic lamprophyres: trace element data from Arizona minettes. Earth Planet. Sci. Lett. 57, 305-312.

Rosa, M.L.S., 1999. Geologia, geocronologia, mineralogia, litogeoquímica e petrologia do Batólito Monzo-Sienítico de Guanambi-Urandi (SW-Bahia). Doctoral Thesis. Universidade Federal da Bahia, Salvador, Brazil, p. 186.

Sabatier, H., 1991. Vaugnerites: special lamprophyre-derived mafic enclaves in some Hercynian granites from western and central Europe. In: Didier, J., Barbarin, B. (Eds.), Enclaves and Granite Petrology. Elsevier, Amsterdam, The Netherlands, pp. 63-82.

Scott, B.H., 1979. Petrogenesis of kimberlites and associated potassic lamprophyres from central west Greenland. In: Boyd, F.R., Meyer, H.O.A. (Eds.), Kimberlites, Diatremes and Diamonds: Their Geology, Petrology and Geochemistry. American Geophysical Union, pp. 190205.

Silva, A.B., Liberal, G.S., Sad, J.H.G., Issa Filho, A., Rodrigues, C.S., Riffel, B.F., 1988. Geologia e petrologia do Complexo Angico dos Dias (Bahia, Brasil): uma associação carbonatítica pré-cambriana. Geochim. Brasiliensis 2, 81-108.

Souto, P.G., 1972. Geologia e petrografia da área de Potiraguá-Bahia. Tese de Doutorado, Universidade de São Paulo, São Paulo, Brasil, p. 65.

Teixeira, L.R., 1996. O Complexo Caraíba e a Suíte São José do Jacuípe no Cinturão Móvel Salvador-Curaça (BA, Brasil): petrologia, geoquímica e potencial metalogenético. Doctoral thesis. Universidade Federal da Bahia, Salvador, Brazil.

Thompson, R.N., Leat, P.T., Dickin, A.P., Morrison, M.A., Hendry, G.L., Gibson, S.A., 1989. Strongly potassic mafic magmas from lithospheric mantle sources during continental extension and heating: evidence from Miocene minettes of northwest Colorado, USA. Earth Planet. Sci. Lett. 98, 139-153.

Vasconcelos, P., Becker, T., 1992. A idade da mineralização aurífera no depósito da Fazenda Brasileiro, Bahia, Brasil. Workshop em Metal- 
ogênese: Pesquisas atuais e novas tendências. UNICAMP (Campinas, Brazil), Boletim de Resumos, p. 29.

Velde, D., 1969. Les micas des lamprophyres: kersantites, minettes, et lamproites. Bulletin de la Societé Française de Mineralogie et Cristallographie 92, 203-223.

White, W.M., 1985. Sources of the oceanic basalts: radiogenic isotopic evidence. Geology 13, 115-118.
Wilson, M., 1989. Igneous Petrogenesis. Chapman \& Hall, New York, USA, p. 466.

Wyman, D., Kerrich, R., 1988. Alkaline magmatism, major structures, and gold deposits: implication for greenstone belt gold metallogeny. Econ. Geol. 83, 454-461.

Zindler, A., Hart, S., 1986. Chemical geodynamics. Ann. Rev. Earth Planet. Sci. 14, 493-571. 